\title{
RESEARCH
}

\section{The structure of Polish numerically-quantified expressions}

\author{
Paulina Lyskawa \\ University of Maryland, College Park, US \\ lyskawa@umd.edu
}

Cross-linguistically, numerically-quantified expressions vary in terms of their internal syntactic structure (e.g. the category of the numeral, its position in the nominal projection) as well as interaction with the external syntax (e.g. occurring in the subject positions, determining agreement and concord). Here, I investigate Polish numerically-quantified expressions of the 5+ type, such as pięć czarownic 'five witches', focusing on three morphosyntactic properties: the genitive case on the quantified noun, the accusative case on the numeral, and the occurrence of 3SG neuter verbal agreement. I argue that all of these properties can be captured within existing theories of case and agreement, in terms of a null head that takes the quantified noun phrase as its complement, and a numeral phrase as its specifier. Genitive on the noun is structural, accusative on the numeral is licensed by a null preposition, and default agreement is a result of the case-discriminating nature of verbal agreement. This proposal has implications for the broader theory of agreement and case assignment in Slavic languages and beyond.

Keywords: syntax; morphology; numerals; agreement; case; Polish

\section{Introduction}

The behavior of numerically-quantified expressions (NQEs) like pięć czarownic 'five witches' has been an ongoing puzzle for Slavic linguistics for decades. It spans some of the core aspects of syntactic inquiry: phrase structure, case and agreement. Particularly, NQEs with the cardinal numerals 5-20 show an unusual pattern. First, consider (1) and (2) below: ${ }^{1}$

$$
\begin{aligned}
& \text { Bona fide noun phrase subject } \\
& \text { Przyjecha-ł-y straszn-e czarownic-e. } \\
& \text { arrive-PST-3PL.F scary-3PL.F witch(F)-PL.NOM } \\
& \text { 'Scary witches arrived.' }
\end{aligned}
$$

\section{NQE subject \\ Przyjecha-ł-o pięć czarownic- $\varnothing$. \\ arrive-PST-3SG.N five witch(F)-PL.GEN \\ 'Five witches arrived.'}

The difference in verbal agreement suggests that the structures in (1) and (2) are not equalthe numeral pięć 'five' does not behave like the AP modifier (straszn-e 'scary-3PL.F'). The first observation is about verbal agreement-the verb agrees with the noun in $\varphi$-features in (1), while the parallel (2) with an NQE shows 3SG.N agreement morphology. Second, the noun in (1) is marked with nominative while the quantified noun in (2) is marked with

\footnotetext{
${ }^{1}$ A list of glossing abbreviations is provided at the end of this paper.
} 
genitive. Moreover, demonstratives, which usually display case concord with the head noun, need not match the case of the quantified noun in NQEs. This is demonstrated in (3):

Demonstrative mismatching the case of the quantified noun
Przyjecha-ł-o te sześc czarownic- $\varnothing$.
arrive-PST-3SG.N DEM.PL.NOM/ACC six witch(F)-PL.GEN
'These six witches arrived.'

\author{
Demonstrative matching the case of the quantified noun \\ Przyjecha-1-o tych sześć czarownic- $\varnothing$. \\ arrive-PST-3SG.N DEM.PL.GEN six witch(F)-PL.GEN \\ 'These six witches arrived.'
}

While it is not immediately clear which constituent is modified by the demonstrative in (3) - the entire NQE or just the numeral-the morphology of the demonstrative suggests that there is some non-genitive element in the phrase, of which the demonstrative is a dependent. Nevertheless, case syncretism (as is common across Slavic) makes it difficult to determine exactly what the case marking of the demonstrative is, based on a single example like (3).

Early philologists noticed the peculiar patterns associated with NQEs across Slavic and described its basic facts (Małecki 1863; Szober 1928). Ever since, linguists have been trying to capture these facts, incrementally uncovering more unusual NQE behavior (Corbett 1978; Franks 1994; Ionin and Matushansky 2004; 2018; Przepiórkowski 2004; Bailyn \& Nevins 2008; Pesetsky 2013; a.o.). NQEs occur frequently and the acceptability judgments for these basic NQE patterns are robust. Yet there is no consensus with respect to the proper modeling of NQEs. Various models for the structure of NQEs cover different parts of the data, but the research on NQEs continues, as there remains more to explain.

In this paper, I will show why this construction may be of interest to syntacticians beyond the Slavic circle. My goal in this paper is to build on this existing data and fill some gaps in addressing the relevant issues in a systematic way. One of the most prevailing questions is the source and nature of the genitive case marking on the quantified noun, as in (2). Further, I will argue that with the proper modeling of the internal and external syntax of numerically-quantified expressions, we can use existing theories of case assignment-in particular, Norris' (2018) proposal-to capture the empirical facts. As a bonus, the agreement facts fall out naturally as a language universal, rather than a language-specific rule. Finally, I will explore the source and nature of the non-genitive case marking on the modifiers, as exemplified in (3).

The paper is structured as follows: first, in Section 2, I introduce basic facts about the morphosyntax of Polish relevant for the discussion of NQEs; Section 3 starts with some fairly uncontroversial assumptions about the structure of NQEs, which have been put forth in the literature; then, it discusses the question of what the head of an NQE is, as well as the position of NQEs in the clause (i.e., their external syntax); finally, it proposes a concrete structure for NQEs. In Section 4, I offer a new analysis of the source and nature of genitive case on the quantified noun, based on a recent proposal for NQEs in Finnish (Norris 2018); then, I compare it briefly to an alternative proposal for Russian (Bailyn 2004). In Section 5, I present evidence for accusative case within NQEs and discuss its source and nature in light of the previous discussion of genitive case. Section 6 concludes.

A note of clarification concerning terminology is in order. There has been considerable debate on whether Slavic languages have a DP layer in general (see, for example, Bošković 2008 and references therein). I use the terms noun phrase or NP/DP for short 
in a theory-neutral way, as my analysis does not depend on this distinction and I remain agnostic as to the exact categorical status of full noun phrases in Polish. Similarly, I use the term numeral atheoretically, as a shorthand for a group of expressions that are intuitively unified by a shared semantics of cardinality. Finally, I use the term numerically-quantified expressions, NQEs, atheoretically as well: it is a shorthand for a group of expressions that are composed of a numeral that quantifies a noun phrase. Therefore, a paucal NQE is an NQE with a paucal numeral, a non-paucal $5+$ NQE is an NQE with a non-paucal $5+$ numeral, and so forth.

\section{$2 \varphi$-features, case and agreement morphology in Polish - a brief overview}

This section presents some basic morphological facts regarding $\varphi$-features, case, and agreement in Polish, and can be used as a reference for understanding the data and analysis in the subsequent sections.

\section{$2.1 \varphi$-features}

Polish generally distinguishes between singular and plural number, with some residual dual forms. It has five grammatical gender categories - masculine human (M1), masculine animate non-human (M2), masculine inanimate (M3), ${ }^{2}$ feminine, and neuter. In the plural, morphosyntax collapses the last four categories and distinguishes only plural masculine human (typically called virile in Slavic linguistics) from everything else, i.e., plural masculine non-human, as well as feminine and neuter plurals regardless of their animacy. (This category is called non-virile.) A mixed group is classified as virile as long as at least one member is a masculine human.

\begin{tabular}{|c|c|c|c|c|c|}
\hline & \multicolumn{3}{|l|}{ MASCULINE } & \multirow[t]{2}{*}{ FEMININE } & \multirow[t]{2}{*}{ NEUTER } \\
\hline & HUMAN & NON-HUMAN ANIMATE & INANIMATE & & \\
\hline SINGULAR & \multicolumn{2}{|r|}{ M1 and M2 } & M3 & $\mathrm{F}$ & $\mathrm{N}$ \\
\hline PLURAL & M1 (VIRILE) & \multicolumn{4}{|c|}{ M2, M3, F, and N (NON-VIRILE) } \\
\hline
\end{tabular}

Accordingly, the $\varphi$-features in examples (1)-(4) should in fact be glossed as NON-VIRILE. In the remainder of this paper, I will adhere to this traditional Slavic convention.

\subsection{Agreement and concord}

Demonstratives and adjectives show concord with the case, gender and number of the noun they modify. Verbs in Polish typically agree with their nominative subjects in number, person, and gender, for at least some Tense/Aspect/Mood (TAM) forms. There is no object agreement in Polish. (See the Appendix for the relevant verbal agreement paradigm.)

\subsection{Case}

There are 7 cases in Polish: nominative, accusative, genitive, dative, locative, instrumental and vocative, as shown in Table in (6). Some of the case forms appear in multiple syntactic contexts, e.g. genitive appears in partitive constructions, on negated objects, on complements of some prepositions, etc. This does not mean that the mechanism of genitive assignment

\footnotetext{
${ }^{2}$ One of the reviewers rightly points out that there are exceptions to the animacy classification. For example, babsztyl denotes a nasty woman but syntactically behaves like M2, i.e., masculine animate. Indeed, these masculine subcategories, just like the other two categories of feminine and neuter, are part of abstract grammar but the labels do not always match what is known from the real world. This behavior is entirely typical of gender systems cross-linguistically. For example, German Mädchen 'girl' is neuter and Arabic ha:mil 'pregnant person' is masculine.
} 
in all these constructions is identical. For example, genitive in one construction may be structural and genitive in another construction may be inherent, even though both types of genitive have an identical surface form. Which cases are structural and which are inherent is a matter of some debate in Slavic linguistics (Franks 1995 and Rutkowski 2002 on genitive in quantified structures, Franks 1995 on dative subjects, Bailyn 2001 on predicative instrumental). Finally, there is a great deal of morphological syncretism, which the next section discusses in more detail.

\subsection{Forms of the nominal suffix}

Nominals usually carry a suffix that is a fusional exponent of case, gender and number. However, the declension system is very complex. The exact form of this morpheme may depend on the phonological shape of the stem. Moreover, some nouns decline according to a different gender class than their own, e.g. mężczyzna 'man' is masculine human but declines according to the feminine pattern. In sum, each noun declines according to one of almost 150 patterns. I refer the curious reader to a dictionary, such as Wielki Słownik Języka Polskiego (wsjp.pl), for detailed information. For the purposes of this paper, I provide declension for the two most frequently used nouns in my examples-czarownica 'witch' and czarodziej 'wizard' in (6).

\begin{tabular}{lll|ll}
\multicolumn{5}{c}{ Declension of czarodziej 'wizard' and czarownica 'witch'. } \\
\hline & MASCULINE & & FEMININE & \\
& SINGULAR & PLURAL & SINGULAR & PLURAL \\
\hline NOMINATIVE & czarodziej- $\varnothing$ & czarodziej-e & czarownic-a & czarownic-e \\
ACCUSATIVE & czarodziej-a & czarodziej-ów & czarownic-e & czarownic-e \\
GENITIVE & czarodziej-a & czarodziej-ów & czarownic-y & czarownic- $\varnothing$ \\
DATIVE & czarodziej-owi & czarodziej-om & czarownic-y & czarownic-om \\
LOCATIVE & czarodziej-u & czarodziej-ach & czarownic-y & czarownic-ach \\
INSTRUMENTAL & czarodziej-em & czarodziej-ami & czarownic-a & czarownic-ami \\
VOCATIVE & czarodziej-u & czarodziej-e & czarownic-o & czarownic-e \\
\hline
\end{tabular}

The forms of some suffixes are syncretic, e.g. in the masculine singular and plural, accusative and genitive are identical; and in the feminine plural, nominative and accusative are identical. Due to this fact, using surface morphology to diagnose the underlying case values can be quite challenging. In my glossing, I sometimes provide two or three cases per morpheme, to represent syncretism. I do not do so in order to obscure the pattern, but rather to acknowledge the range of analytical possibilities that these syncretisms give rise to.

\section{Polish NQEs: Basics of the structure}

In this section, I elaborate on the basic data from Polish numerals provided in section 1. This section starts with the least controversial aspect, i.e., the inability of the numeral or the NQE to control verbal agreement. Then, it provides a critical evaluation of analyses of the external syntax of NQEs, namely the position of the NQE within the clause, and of their internal syntax, namely the question of whether the numeral is a head or a phrase. It concludes with a proposal for the basic structure of NQEs.

\subsection{Types of numerals}

Before focusing on the properties and structure of NQEs like pięc czarownic 'five witches', let me discuss the different types of numerals in Polish. Polish has several types of numerals (Sadowska 2012): 


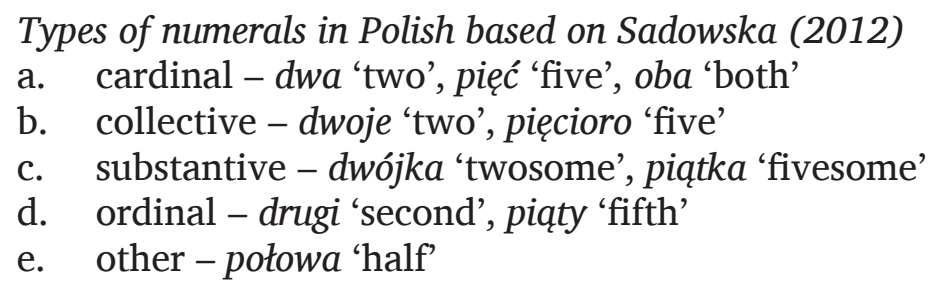

The use of collective numerals is semantically and syntactically restricted to quantify animate neuter nouns like dzieci 'children', some animal offspring like szczenięta 'puppies', groups of humans of varying genders like studenci 'students' and some pluralia tantum like drzwi 'doors'. A reviewer observes that morpho-syntactically, this class of numerals behaves sometimes like the cardinal $5+$ numerals discussed in this paper, and sometimes like pseudo-partitives. Furthermore, there is wide variability in linguistic behavior of this class of numerals among Polish speakers. I will not pursue an analysis of this class of numerals, but my hope is that this paper might spark interest in this area as well. Throughout this paper, I focus only on cardinal numerals (7a). Cardinal numerals can be split into three subcategories based on their syntactic properties (Miechowicz-Mathiasen 2011; cf. Corbett 1978 for Russian):

Classes of cardinal numerals distinguished by their syntactic properties

a. Paucal numerals (2-4) - adjectival in their behavior

b. $5+$ numerals $(5-20,30, \ldots 100)-$ mixed adjectival/nominal in their behavior

c. Higher numerals (1000 and so on) - nominal in their behavior ${ }^{3}$

Here, I will discuss $5+$ numerals and the NQEs built from them in greatest detail. This division into paucal vs. $5+$ numerals, with respect to the alignment between the cardinality of the numeral and its syntax, is in fact more complex. Virile paucal numerals come in two varieties: (i) adjectival, e.g. dwaj 'two', like all other paucal numerals and (ii) mixed adjectival/nominal, e.g. dwóch 'two', like 5+ numerals. For the sake of simplicity, I will ignore subset (ii) and use the term paucal as a shorthand for numerals that behave syntactically like adjectives, and $5+$ numerals for numerals that show mixed adjectival-nominal syntactic behavior.

The reader should keep in mind that a $5+$ numeral (e.g. pięć 'five') is not necessarily the same as a $5+N Q E$ (e.g. pięć czarownic 'five witches'). The numeral is a part of the NQE, but it is not necessarily the head of the NQE (contrary to what is often assumed in the literature). There are cases where it is hard to distinguish whether a particular grammatical pattern should be ascribed to a property of the numeral vs. a property of the entire NQE. I will take care to appropriately flag these.

\subsection{Verbal agreement}

As noted in the Introduction, when a $5+\mathrm{NQE}$ is in subject position, the finite verb exhibits unexpected agreement morphology:

$$
\begin{aligned}
& \text { Typical agreement with non-virile subject } \\
& \text { Straszne czarownic-e przyjecha-t-y. } \\
& \text { scary witch-NVIR.NOM arrive-PST-NVIR } \\
& \text { 'Scary witches arrived.' }
\end{aligned}
$$

\footnotetext{
${ }^{3}$ Many of the higher numerals can follow two patterns: mixed (as $5+$ numerals), or nominal. The literature characterizes the pattern of some of the higher numerals as nominal based on a number of factors: the morphological expression of case, number and gender on these numerals, the case and phi concord with their modifiers, the presence of productive diminutive forms, and the consistent assignment of genitive to the quantified noun in all positions.
} 


\author{
3SG.N agreement marking with an NQE subject \\ Pięć czarownic- $\varnothing$ przyjecha-ł-o. \\ five witch-NVIR.GEN arrive-PST-3sG.N \\ 'Five witches arrived.'
}

In (9), agreement tracks the $\varphi$-features of the modified noun, while in (10), when the same noun is part of an NQE, the verb exhibits 3SG.N agreement. In fact, in contrast to the frequently discussed Russian pattern (Franks 1995: 101), 3SG.N agreement is the only option here:

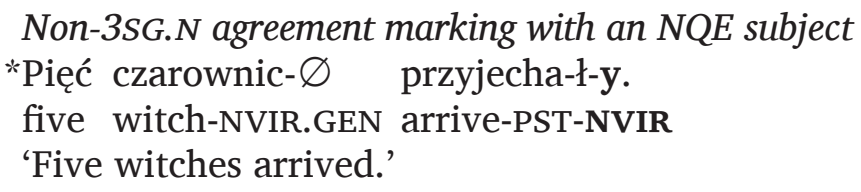

The above example shows that the quantified noun cannot itself control verbal agreement: the $\varphi$-features of (pięć) czarownic '(five) witches' are not what shows up on the verb. It is not immediately clear why the agreement morphology on the verb is 3SG.N regardless of the $\varphi$-features of the noun: under typical conditions, $\varphi$-agreement on the verb comes from the nominative subject. It might seem plausible to assume that the agreement morphology we see in this case comes from the numeral itself-for example, because the numeral itself bears 3SG.N $\varphi$-features, and serves as the head of the entire NQE, which in turn controls verbal agreement. I will show, however, that this 3SG.N agreement morphology does not come from the NQE. First, note that a 3SG.N demonstrative-even though it is prescribed by grammars-is rejected even by educated speakers: ${ }^{4}$

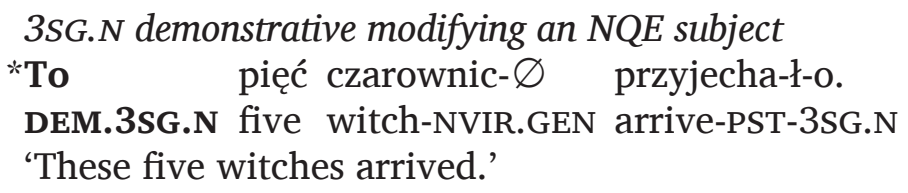

Furthermore, observe that coordination of two neuter noun phrases (each of which is singular) in subject position results in plural agreement on the finite verb: ${ }^{5}$
Coordinating two neuter singular noun phrases
Wiadr-o i pudełk-o upad-ł-y
na podłog-ę.
bucket(N)-NOM and box(N)-NOM fall-PST-NVIR on floor-ACC
'A bucket and a box fell on the floor.'

Contrary to the pattern above, coordinating two NQEs does not yield plural agreement, as the unacceptability of (14) shows. Instead, agreement needs to be 3rd singular neuter, as in (15)—this, despite the clear semantic plurality of the two coordinated conjuncts:

\footnotetext{
${ }^{4}$ I thank a reviewer for this observation.

${ }^{5}$ A reviewer questions the assumption that gender resolution is calculated deterministically. The issue of gender resolution under coordination in Polish and in Slavic more broadly is quite complex, and involves an interaction of syntax, semantics and pragmatics (Ruda 2011). There are also some cases of coordination (usually of mixed animacy) where speakers' judgments differ-suggesting that there is no (one) grammatical rule accounting for such resolution. Whatever the analysis may be, what is relevant for the coordination of NQEs is number resolution, which is deterministic for nominal conjuncts: coordination of non-NQE nominal phrases always results in plural (pace contexts where single conjunct agreement is allowed), while coordination of NQEs never results in plural agreement.
} 
Plural agreement with coordinated NQEs

*Pięć czarownic- $\varnothing$ i sześć wróżek- $\varnothing$ przyjecha-ł-y do miast-a. five witch-NVIR.GEN and six fairy-NVIR.GEN arrive-PST-NVIR to city-GEN 'Five witches and six fairies arrived in the city.'

3SG.N agreement with coordinated NQES

Pięć czarownic- $\varnothing$ i sześć wróżek- $\varnothing$ przyjecha-1-o do miast-a. five witch-NVIR.GEN and six fairy-NVIR.GEN arrive-PST-3SG.N to city-GEN 'Five witches and six fairies arrived in the city.'

This suggests that the 3SG.N verbal agreement found with NQEs is not a result of a typical mechanism of valuing/checking the $\varphi$-features of the verbal head against a phrase that carries bona fide 3SG.N features. Instead, 3SG.N morphology on the verb in examples like (10) appears to be a morphological default. It has been proposed that verbs cannot agree with an NQE because of its position within the clause. Only arguments in subject position—often taken to be Spec TP/IP—can be agreed with. Pesetsky (1982) claims that NQEs that are not agreed with because they do not occupy Spec TP/IP. In the next section, I will show that NQEs in Polish pass typical subjecthood diagnostics, and so their inability to agree is does not seem attributable to their external syntax (e.g. their structural position within the clause, or other clausal correlates of subjecthood; see McCloskey 1997; Poole 2016).

\subsection{The subjecthood of NQES}

In this section, I show that NQEs can behave as typical subjects in Polish, and therefore, that the unusual verbal agreement associated with them is not attributable to their position in the clause. Dziwirek (1994) and Citko (2011: 121-125) use four subjecthood diagnostics for Polish, to contrast the status of nominative subjects and dative subjects on the one hand, with that of fronted indirect dative objects on the other:

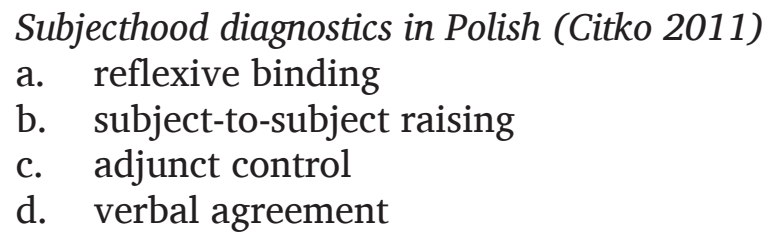

Bona fide nominative subjects pass all four diagnostics; dative subjects pass all but the verbal agreement diagnostic (due to the agreement probe being relativized to nominative, an issue which I return to later); whereas fronted dative indirect objects fail all four diagnostics.

Applying the same tests to NQEs shows that they behave as canonical subjects. First, Polish distinguishes between a reflexive possessor swój that targets all and only subjects, and a non-reflexive possessor jego elsewhere. Subject NQEs necessitate the reflexive possessor, and cannot bind a non-reflexive one:

\footnotetext{
NQE subject and a possessed object

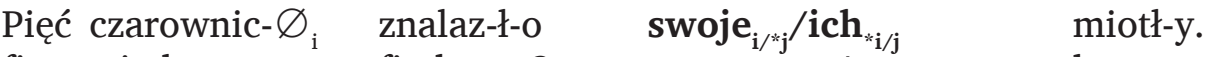

five witch-NVIR.GEN find-PST-3SG.N POSS.REFL/POSS.NREFL broom-NVIR.ACC

'Five witches found their brooms.'
}

In the example above, binding of the possessor by the NQE requires the use of a reflexive form, as would be the case with a regular nominative or dative subject (as shown by Citko 2011: 125). Previous results contrasting dative subjects and fronted dative indirect objects 
suggest that the reflexive binding diagnostic taps into subjecthood per se-as opposed to, say, nominative case marking. ${ }^{6}$

The second diagnostic, subject-to-subject raising, is also applicable to NQEs: ${ }^{7}$

\section{NQE subject raising}

Pięć czarownic- $\varnothing$ wydawa-ł-o się rzuca-ć urok.

five witch.NVIR.GEN seem-PST-3SG.N REFL cast-INF spell(M3).ACC

'Five witches seemed to be casting a spell.'

In the example above, the NQE subject of the lower clause has raised into the non-thematic subject position of 'seem'. This type of raising can only apply, in Polish, to phrases that were subjects in their clause of origin.

Third, depictive adjuncts headed by po can only be controlled by subjects (Dziwirek 1994; Citko 2011): 8

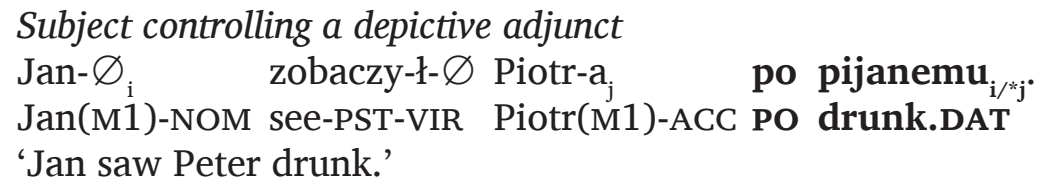

Depictive adjuncts are licensed by subjects regardless of the subject's semantic role, be it Agent as in (19) above, or Patient, as in (20):

$$
\begin{aligned}
& \text { Passive subject controlling a depictive adjunct } \\
& \text { Jan- } \varnothing_{\mathrm{i}} \text { byl- } \varnothing \text { widzi-an-y po pijanemu }{\mathrm{i} / \mathrm{j}^{\mathrm{j}}} \text {. } \\
& \text { Jan(M1)-NOM COP-M.SG see-PASS-M.SG PO drunk.DAT } \\
& \text { 'Jan was seen drunk.' }
\end{aligned}
$$

Crucially, NQEs can also control depictive adjuncts:

$$
\begin{aligned}
& \text { NQE subject controlling a depictive adjunct } \\
& \text { Pięć czarownic- } \varnothing \text { lata-ł-o po pijanemu. } \\
& \text { five witch-NVIR.GEN fly-PST-3SG.N Po drunk.DAT } \\
& \text { 'Five witches were flying while drunk.' }
\end{aligned}
$$

The acceptability of (21) is thus a third piece of evidence that NQEs behave like bona fide subjects in Polish.

Finally, with respect to verbal agreement, it is clear from the data above that (at least some) NQEs fail the verbal agreement test, similarly to dative subjects (Citko 2011). However, it can be argued that for agreement to obtain, the goal needs to be accessible

\footnotetext{
${ }^{6}$ Finding other non-nominative subjects such as ECM subjects would further corroborate that reflexive possessors care about the structural position of the licensor rather than its case marking. However, Przepiórkowski (2004) argues that Polish does not have any ECM constructions. Additionally, the expectation is that a reflexive possessor would not be able to be bound by a nominative non-subject, e.g. nominative objects in constructions with dative subjects; again, I was unable find any examples of true nominative non-subjects in Polish. The dative-subject verbs mentioned in the main text lack objects altogether.

${ }^{7}$ As pointed out by an anonymous reviewer, raising is not a good diagnostic in Polish which has a very flexible word order. According to this diagnostic, adverbs in 0 -argument predicates in Polish would pass the subjecthood diagnostic.

${ }^{8}$ A reviewer points out that for some speakers these adjuncts are only loosely rather than strictly subjectoriented - there are examples in the corpus where the adjuncts are controlled by non-subjects. However, in targeted elicitations my consultants show a strong preference towards the adjuncts being controlled by a subject compared to other readings. Whatever marginally allows other readings for some speakers is yet to be explained.
} 
position and visible to the probe-e.g. by being marked with nominative case. Failing to be marked with nominative results in lack of agreement and the occurrence of default morphology on the verb. The analysis of 3SG.N in NQEs as default agreement has been already proposed by Dziwirek (1990) and Przepiórkowski (1999). Such analyses need not be Polish-specific. Cross-linguistically, agreement is case-sensitive (Bobaljik 2008, a.o.). If a language allows agreement only with nominative (or unmarked) case, the lack of an argument with appropriate case will result in default agreement (Preminger 2014, a.o.). I will show in Section 5 that there is no nominative anywhere within an NQE, and therefore, the conditions arise for default agreement in this case.

In summary, NQEs pass subjecthood diagnostics for Polish with the exception of triggering verbal agreement, which I suggested does not obtain for independent reasons. Thus, the evidence points to these NQEs being canonical subjects. Consequently, the occurrence of 3SG.N agreement morphology cannot be attributed to the external syntax of NQEs, i.e., their position within the clause. The invariant 3SG.N agreement morphology must arise for a different reason.

\subsection{Polish numerals are phrases}

I will now turn to the status of the numeral within the NQE: is it the head of the phrase, as commonly assumed, or is the numeral itself phrasal? Cross-linguistically, both options have been argued for (Franks 1994; Bailyn 2004; Shlonsky 2004; Pereltsvaig 2006; Danon 2012). I will show that the data used as evidence for Polish numerals being heads canand in fact, must-be accounted for differently. Using evidence from split phrases, complementation, and complex numerals, I will demonstrate that numerals project their own phrase, which I label Numerical Phrase (NmrP).

\subsubsection{Non-paucal numerals as heads}

Most of the literature on Polish treats higher $(1000+)$ numerals as bona fide nouns, and $5+$ numerals as exceptional nominals, due to the relation of the latter to the case found on the quantified noun (Franks 1995; Przepiórkowski 1999; Miechowicz-Mathiasen 2011). The pattern whereby the case on the quantified noun depends on the particular numeral is in fact found in several languages (see Nelson \& Toivonen 2000 for Inari Sami; Ionin \& Matushansky 2006 for Russian; Norris 2018 for Estonian and Finnish). If we assume that a non-paucal numeral is the (sometimes deficient) head of the expression, we can attribute the relevant case-assigning properties to the numeral itself, treating it as the head of the entire NQE.

Much of the literature on Polish numerals argues (or simply assumes) that they are the heads of the NQE, and that they take the quantified noun phrase as their complement (Franks 1994: 157; Przepiórkowski 1996: 211; Rutkowski 2002: 12; 2009: 154; Miechowicz-Mathiasen 2011: 22; 2012: 67; Klockmann 2012: 96; Przepiórkowski \& Patejuk 2012; Wagiel 2018: 436). Some of this work was done in the HPSG or LFG frameworks, where the status of heads is not entirely equivalent to their status in the GB and Minimalist frameworks (cf. Przepiórkowski \& Patejuk 2012). Reviewing this body of literature is beyond the scope of the current paper; in studies done within the GB and Minimalist frameworks, the fact that the case on the quantified noun phrase co-varies with the type of numeral has been taken as an argument that the numeral is a head that directly assigns case to the complement noun. This, however, is not a necessary conclusion. An alternative would be to attribute case assignment to a null functional head above a quantified noun phrase (Bošković 2006). I will show that such a null head is in fact independently required, given the independent evidence for the phrasal nature of the numeral. To the best of my knowledge, among the research on Polish NQEs, only Rappaport (2003: 126) 
assumes that the head of an NQE is the quantified noun, and Willim (2015: 157) argues extensively that the numeral projects a phrase in the specifier of an NQE.

Building on these studies, whose synopses I provide below, I will argue that: (i) the numeral itself forms a Numerical Phrase (NmrP), located in the specifier of a larger NumericallyQuantified Phrase (NQP), (ii) the Numerical Phrase enters into an agreement relationship with the (null) $\mathrm{NQ}^{0}$ head, and (iii) it is this $\mathrm{NQ}^{0}$ head that is responsible for the case found on the quantified noun.

\subsubsection{Split Phrases}

Willim (2015: 162) shows that the numeral can be linearly separated from the quantified noun. She proposes to analyze this construction as the result of Left Branch Extraction: an operation which dislocates determiners, possessors, and adjectives out of nominal phrases, and which always targets phrasal constituents (Bošković 2005: 4).

Despite the flexible word order of Polish, not everything can be freely extracted from the noun phrase. As noted, numerals can indeed be extracted:
Numeral separated from its quantified noun
Pięć chc-ę zaprosi-ć czarownic- $\varnothing$.
five want-1SG invite-INF witch-NVIR.GEN
'I want to invite five witches.'

Compare this to extraction of a head noun, whose NP/DP complement stays behind:
Head noun separated from its noun complement
*Student-ów chc-ę zaprosi-ć fizyk-i.
student-VIR.ACC want-1SG invite-INF physics(F)-GEN
'I want to invite students of physics.'

As shown here, extracting the head noun alone is ungrammatical. Since the numeral 'five' in (22) can undergo Left Branch Extraction, this argues against its status as a head which takes the noun (phrase) as its complement. If a numeral is indeed a phrase, then the contrast between (22) and (23) can be easily explained. ${ }^{9}$

There exist potential reservations concerning LBE in general, but I argue that they do not hold for Polish in particular. Pereltsvaig (2008) argues that such splits in colloquial Russian are not instances of sub-extraction. Specifically, she shows that they are not sensitive to islands, and therefore cannot involve movement. She proposes instead that the entire phrase is copied in the left periphery, and only partially pronounced at PF-an

\footnotetext{
${ }^{9}$ A reviewer points out that the contrast between (22) and (23) almost fully disappears when a contrastive coda is added:
}

(i) Numeral separated from its quantified noun + contrastive coda Pięć chcę zaprosić czarownic, a nie cztery. five want.1SG invite witches and not four. 'I want to invite five witches rather than four.'

(ii) Head noun separated from its noun complement + contrastive coda ?Studentów chcę zaprosić fizyki, a nie wykładowców. students want.1SG invite physics and not teachers 'I want to invite students of physics rather than teachers.'

My consultants confirm the observation that (ii) improves with a contrastive coda and approaches full acceptability. However, some amount of contrast is still preserved. It might be the case that we are dealing with a difference in derivations between the sentences with and without the contrastive marker. See Corver (1992) for the distinction between base-generation, scattered deletion and other possible derivations of LBE. 
instance of scattered deletion (Fanselow \& Čavar 2002; Ott \& de Vries 2016). Which part of the phrase is pronounced on the left and which on the right is almost unrestricted in Russian. Pereltsvaig provides one crucial example where the head is separated from the rest of the phrase:

Head separated from the rest of the phrase in Russian (from Pereltsvaig 2008: 34, bolding is original and indicates contrastive focus)

Protiv on vystupal sovetskoj vlasti, a ne za (neë). against he demonstrated Soviet regime and not for (it) 'He demonstrated AGAINST the Soviet regime and not FOR it.'

In Russian, the head can be split from the rest of the phrase, as in (24)—which suggests that the dislocated constituent in Russian split phrases does not need to be a phrase. Polish differs in this respect; in particular, the equivalent of (24) is unacceptable in Polish:

Head separated from the rest of the phrase in Polish
"Przeciwko demonstrował sowieckiemu reżimowi, a nie za (nim).
against demonstrated Soviet regime and not for (it)
'He demonstrated AGAINST the Soviet regime and not FOR it.'

Hence, the splits in Polish are not of the same nature as their Russian counterparts. I will continue to assume they are a typical case of sub-extraction.

Another challenge to the LBE analysis of split phrases is that the data in (22) might prima facie be analyzed as an instance of Floating Quantifier (FQ) (Alexander Williams p.c.). There are several issues with such an alternative. First, Doetjes (1997: 202) argues that FQs can be phrasal. If so, then even if the data above, (22) instantiates quantifier float, the phrasal nature of the numeral is still tenable. Second, even if Polish FQs were not phrases but heads, it is unlikely that the data above could be an instance of FQ. Quantifier float contrasts with LBE in that quantifier float is clause-bounded (Kayne 1981). This can be tested via a cleft construction, ${ }^{10}$ which involves an additional clause. A small-scale survey on 10 native speakers of Polish shows that clefting both a numeral phrase and a bona-fide quantifier results in rather low acceptability, but nevertheless, there is a difference in acceptability between clefting a numeral phrase (26) and clefting a quantifier like wszyscy 'all' (27): ${ }^{11}$

\footnotetext{
${ }^{10}$ It is important to recognize that Polish clefts might not be typical clefts (Reeve 2010), because of the ban on the inflecting copula, as well as the homophony of the non-inflecting copula (to) with a demonstrative. In sum, only if FQs are indeed heads and further, Polish clefts are not real clefts, does this evidence fail to rule out an FQ analysis of split NQEs. Just in that case does this data fail to provide an argument in favor of a numerals constituting a phrase. Even then, it would not provide an argument for the opposite conclusion; rather, it would be uninformative on the issue.

${ }^{11}$ While the cleft construction shows a contrast between a quantifier and a numeral, there is no such contrast when extracting out of a complement clause with a subjunctive:
}

(i) Numeral extracted out of a complement in a subjunctive
Pieć chcia-ł-am
że-by-ś
zaprosi-ł-a czarownic- $\varnothing$.
five want-PST-1SG.F that-SUBJ-2SG invite-PST-F witch-NVIR.GEN
'I wanted you to invite five witches.'

(ii) Quantifier extracted out of a complement in a subjunctive
Wszystkie chcia-ł-am że-by-ś
zaprosi-ł-a czarownic-e.
all.NVIR want-PST-1SG.F that-SUBJ-2SG invite-PST-F witch-NVIR.ACC

'I wanted you to invite all witches.'

I leave the explanation of this curious lack of contrast in the extraction of numerals vs. quantifiers from subjunctive clauses for further research. 
(26)

Clefted numeral

??To pięć chcia-ł-am zaprosi-ć czarownic- $\varnothing$.

TO five want-PST-1SG.F invite-INF witch-NVIR.GEN

'It was five that I wanted to invite witches.'
Clefted quantifier
*To wszystkie chcia-ł-am zaprosi-ć czarownic-e.
TO all.NVIR want-PST-1SG.F invite-INF witch-NVIR.ACC
'It was all that I wanted to invite witches.'

Crucially, the extraction data in (22) above supports the claim that numerals are phrasal. Other extraction data do not provide any definite evidence in favor or against this analysis. I will now proceed to other empirical evidence that backs the claims of numerals constituting their own phrase.

\subsubsection{Complex numerals}

The second argument in favor of the phrasal nature of numerals in NQEs is that they can be expanded the same way phrases can. The most obvious example comes from complex numerals like dwadzieścia pięć 'twenty-five'. As Ionin \& Matushansky (2006) argue, complex numerals are constructed syntactically, via recursion (multiplication) and/or conjunction (addition). Polish is a strict decimal-based language; two operations produce complex numerals. The first operation involves multiplication of the base-for example, 20 is 2 times 10, 30 is 3 times 10, etc. The second operation involves addition-for example, 12 is 10 and 2, 13 is 10 and 3, etc. Consider the multiplication of the base first:

$$
\begin{aligned}
& \text { NQE with a multiplied base }{ }^{12} \\
& \text { dwa-dzieścia czarownic- } \varnothing \\
& \text { two-ten witch-NVIR.GEN } \\
& \text { 'twenty witches' }
\end{aligned}
$$

We could in principle view the multiplier $d w a$ 'two' as having undergone head-adjunction to dzieścia 'ten'. Crucially, however, the multiplier itself determines the case marking of the base:

$$
\begin{aligned}
& \text { NQE with a base multiplied by } 5+ \\
& \text { pięć-dziesiąt- } \varnothing \text { czarownic- } \varnothing \\
& \text { five-ten-GEN } \quad \text { witch-NVIR.GEN } \\
& \text { 'fifty witches' }
\end{aligned}
$$

What we see here is that the multiplier determines the case marking on the base, in the same way that a numeral determines the case on the quantified noun phrase: when the multiplier is a member of the $5+$ class of numerals, the case of the base changes. Notice that the quantified noun phrase itself in both (28) and (29) is always marked with genitive, regardless of the type of a numeral in the multiplier.

Crucially, adjuncts do not determine the case marking of the constituent they adjoin to. The case marking on 'ten' changes in (29) compared to (28), therefore pięć 'five' cannot be an adjunct. On the other hand, the case marking on the quantified noun phrase depends on the least significant digit:

\footnotetext{
${ }^{12}$ Here, I gloss -dzieścia (nominative) and -dziesiąt (genitive) as 'ten' for the sake of transparency. The alternative suggested by two reviewers is to analyze it as a grammaticalized morpheme analogous to English -ty (in forty, fifty, etc.), since the forms of a free standing 'ten' is dziesięć (nominative) and dziesięciu (genitive). I am agnostic as to the choice between these analytical options. Both would need to refer to locality domains where head-adjunction could not govern the distinction between the two forms.
} 
NQE with a complex numeral with a paucal least significant digit

a. dwa-dzieścia dwie czarownic-e two-ten two witch-NVIR.NOM 'twenty two witches'

b. pięć-dziesiąt dwie czarownic-e five-ten two witch-NVIR.NOM 'fifty two witches'

(31) NQE with a complex numeral with a $5+$ least significant digit

a. dwa-dzieścia pięć czarownic- $\varnothing$ two-ten five witch-NVIR.GEN 'twenty five witches'

b. pięć-dziesiąt pięć czarownic- $\varnothing$ five-ten five witch-NVIR.GEN 'fifty five witches'

Examples (30)-(31) show that the case on the quantified noun phrase depends only on the least significant digit, not the multiplier. (30a) and (30b) have the same paucal leastsignificant digit dwie 'two' and the case marking on the quantified noun phrase is the same regardless of the type of multiplier ( $d w a$ 'two' in (30a) vs. pięć 'five' in (30b)). Examples (31a) and (31b) show the same parallelism, but with a least-significant digit of the $5+$ class. In sum, the multiplier does not determine the case marking on the quantified noun phrase and so, the multiplier cannot be the head of the entire NQP (with the least significant digit undergoing head-adjunction to the multiplier), either.

Finally, the complex numeral in its entirety can be Left-Branch-extracted:

\section{Complex numeral LBE out of NQPS}

a. Dwa-dzieścia przyjecha-ł-o czarownic- $\varnothing$.

two-ten arrive-PST-3SG.N witch-NVIR.GEN

'Twenty witches arrived.'

b. Dwa-dzieścia pięć przyjecha-ł-o czarownic- $\varnothing$. two-ten five arrive-PST-3SG.N witch-NVIR.GEN 'Twenty-five witches arrived.'

The examples above show that the complex numerals can be extracted. Therefore, they must form a phrasal constituent-if a numeral were the head of the entire NQP, LBE would not be possible (see 3.4.2).

This relationship between the multiplier and the base, as well as base and quantified noun phrase (but crucially, not between the multiplier and the quantified noun phrase) would be hard to explain in terms of adjunction. A recursive structure, in which the complex numeral forms a phrase with a multiplier in the specifier position of that phrase, is better suited to capture these facts.

Further evidence for the phrasal nature of numerals comes from the second mechanism for building complex numerals: addition.

NQE with a complex numeral constructed by addition

dwa-dzieścia pięć czarownic- $\varnothing$

two-tenths five witch-NVIR.GEN

'twenty five witches'

Ionin \& Matushansky (2006: 340) argue that addition involves coordination of two cardinal numerals, followed by Right Node Raising (34) or PF-deletion (35). 
Ionin and Matushansky's (2006: 340) structure of complex numerals involving complementation and Right Node Raising

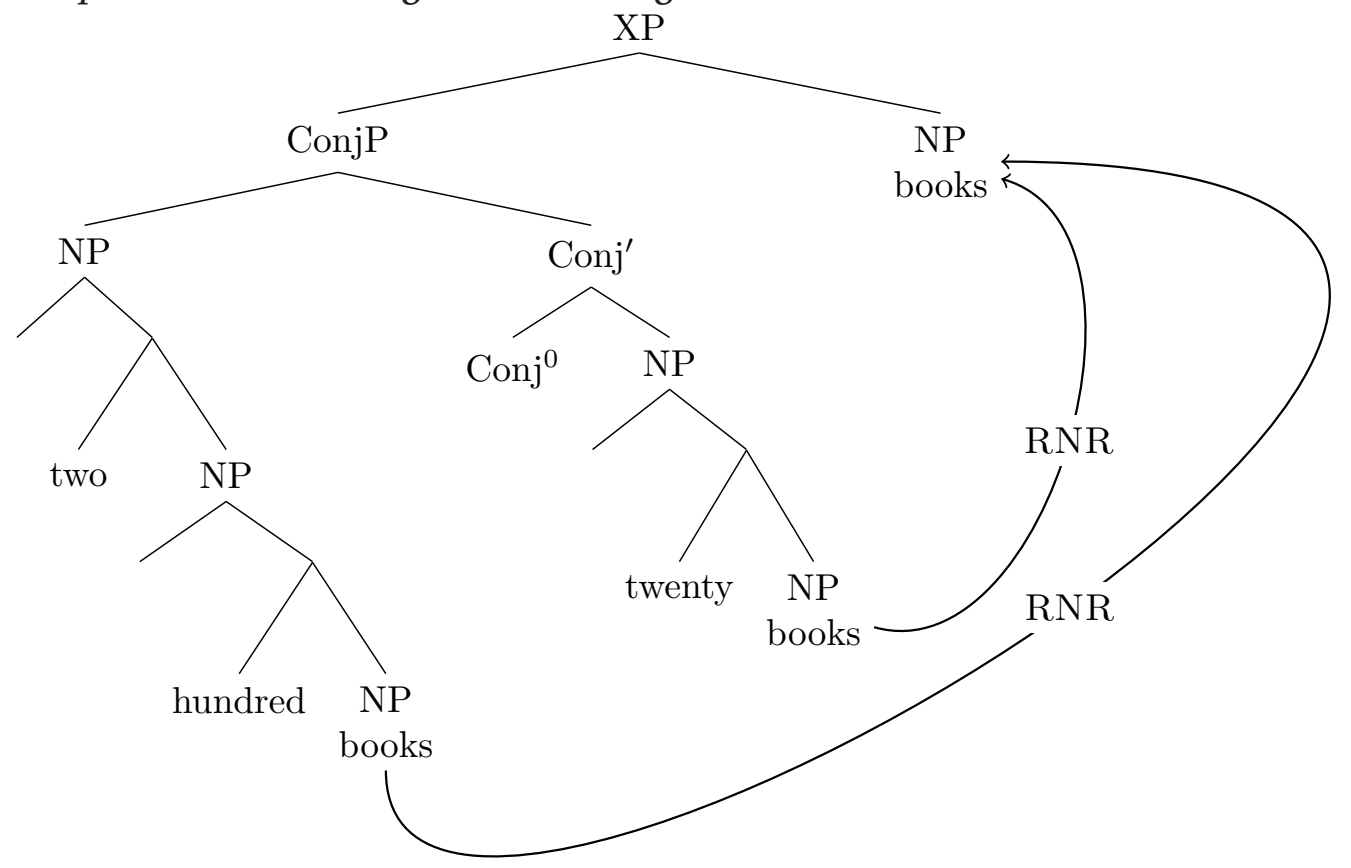

The RNR analysis of complex numerals is problematic for at least one reason. RNR usually influences prosody, i.e., there is a pause immediately before the raised constituent. However, in complex numerals there is no such pause.

The second analysis of complex numerals entertained by Ionin \& Matushansky involves PF-deletion:

$$
\begin{aligned}
& \text { Ionin and Matushansky's (2006: 340) structure of complex numerals involving } \\
& \text { complementation and PF-deletion }
\end{aligned}
$$

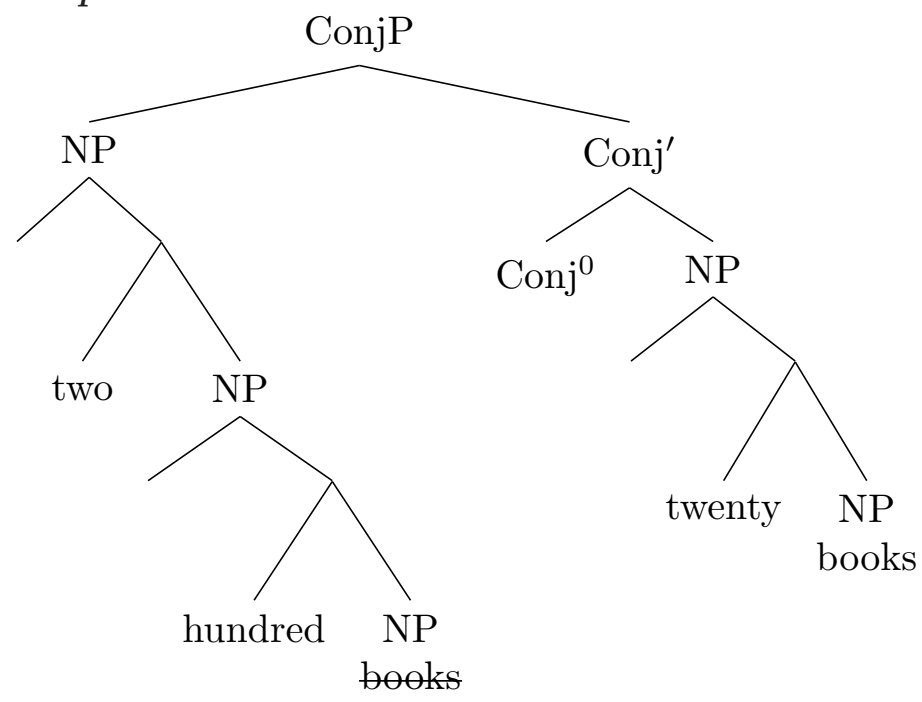

If numerals were heads, either an RNR analysis or a PF-deletion one would be necessary. However, if numerals constitute their own phrase, numerals can be coordinated to the exclusion of the quantified NP/DP, yielding a far simpler account of the patterns above. In sum, the properties of complex numerals-i.e. the case dependencies within complex numerals, and the possibility of LBE—favor the phrasal analysis of numerals. Alternative analyses are 
available but require extra stipulations. The following section will provide further evidence, from a different empirical domain, in favor of the phrasal analysis of numerals.

\subsubsection{Coordination with a simple numeral}

A numeral can be coordinated with a non-numeral phrase like coś 'something':

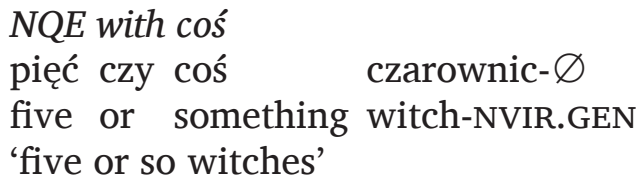

Coordination of a numeral with the phrase coś results in an interpretation when the quantifty denoted by the numeral is approximated rather than exact. This type of coordination cannot be argued to be a coordination of two full NP/DPs followed by RNR and/or PF deletion- * coś czarownic(e) could potentially have a meaning of 'some number of witches', but it is an ungrammatical phrase. However, if the numeral is a phrase then the fact that it can be coordinated with another phrase follows naturally.

\subsection{Proposed structure}

In sections 3.4.1-3.4.4 above I presented arguments in favor of treating numerals in Polish NQEs as phrases of their own, rather than as heads of the NQE. Consequently, the head of the entire NQE phrase must be something else-presumably, a null morpheme. Given these facts, I will assume from this point forward that an NQP has the structure represented in (37).

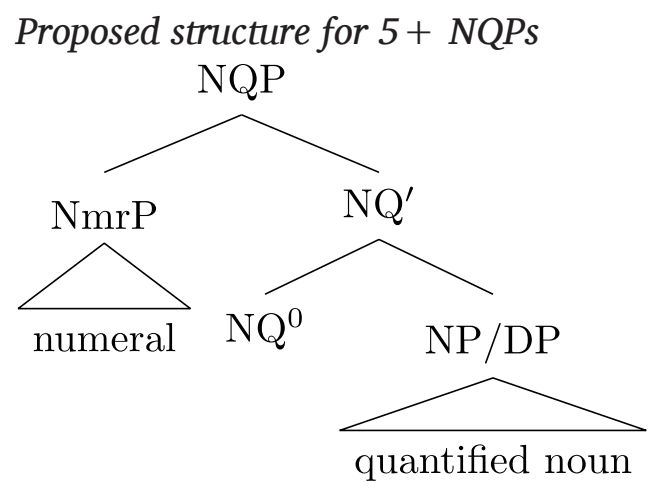

I propose that the head of an NQP is a null functional element that always c-selects for a NmrP in its specifier. Furthermore, I propose that $\mathrm{NQ}^{0}$ is responsible for the unique property of the quantified noun phrase-overridable genitive described in the following section.

Before turning to a more detailed discussion of the syntactic properties of $\mathrm{NQ}^{0}$, let me point out that treating numerals as phrases immediately accommodates the possibility of modifying the numeral and the noun phrase independently of one another. Willim (2015: 162) observes that an accusative modifier does not modify the noun, but the numeral-as evidenced by acceptability of the following phrase:

$$
\begin{aligned}
& \text { NQE with two contradicting modifiers } \\
& \text { niecał-e pięćdziesiąt pełn-ych butelek- } \varnothing \text { win-a } \\
& \text { not.entire-NOM/ACC fifty full-GEN bottle-NVIR.GEN wine-GEN } \\
& \text { 'almost fifty full bottles of wine' }
\end{aligned}
$$


The adjectives niecate 'not entire' and petnych 'full' are contradictory when the two are modifying the same phrase:

Noun phrase with two contradicting modifiers
*niecał-e pełn-e butelek-i win-a
not.entire-NOM/ACC full-NOM/ACC bottle-NVIR.NOM wine-GEN
Intended: 'not entire full bottles of wine'

However, because in (38) these adjectives modify two separate phrases (NmrP and NP/DP, respectively), the phrase is acceptable and generates a non-contradictory interpretation (the bottles are full but there are less than fifty of them). In contrast, these modifiers cannot be licitly combined in the absence of a numeral phrase (39).

\subsection{Interim summary}

In this section, I have shown that $5+$ numerals are not nouns that determine verbal agreement, even though an NQP may occupy the subject position. Furthermore, numerals are not the heads of these phrases. Rather, they are phrases occupying the specifier position of an NQP, as shown in (37).

The following two sections constitute the core of the current analysis: the source and nature of the genitive marking on the quantified noun, and the properties of the numeral with respect to concord phenomena.

\section{Genitive on the quantified noun}

In this section, I propose an analysis of the genitive case found on the quantified noun-phrase in an NQP. This genitive is often described as Quantificational Genitive (Franks 1995). I will first show how the genitive in NQEs differs from the genitive found in other quantificational contexts. Then, I will discuss the source of this case, evaluating both an existing proposal for Russian (Bailyn 2004) and a more recent proposal for Finnish numeral-noun constructions (Norris 2018).

\subsection{Overriding genitive in an NQP}

It has long been observed that the genitive on a quantified noun phrase appears only if the NQP is in a non-oblique position, such as the subject position (which would normally bear structural nominative case), or the direct object position (which would normally bear structural accusative case):

(40) NQP as subject

Przyjecha-ł-o pięć czarownic- $\varnothing$.

arrive-PST-3SG.N five witch-NVIR.GEN

'Five witches arrived.'
NQP as direct object
Widzia-ł-am pięć czarownic- $\varnothing$.
see-PST-1SG.F five witch-NVIR.GEN
'I saw five witches.'

In contrast, when the same NQP is in an oblique position-e.g. it is a complement of a preposition-the entire NQP (i.e., both the numeral and the quantified noun) is marked with the particular lexical case that the preposition in question normally assigns to its complement: 
Preposition assigning genitive case ${ }^{13}$

a. dla czarownic- $\varnothing$

for witch-NVIR.GEN

'for witches'

b. dla pięc-iu straszn-ych czarownic- $\varnothing$

for five-GEN/LOC/DAT scary-NVIR.GEN/LOC witch-NVIR.GEN

'for five scary witches'

(43) Preposition assigning instrumental case

a. $\mathrm{z}$ czarownic-ami

with witch-NVIR.INS

'with witches'

b. $\mathrm{z}$ pięc-ioma straszn-ymi czarownic-ami

with five-INS scary-NVIR.INS witch-NVIR.INS

'with five scary witches'

(44) Preposition assigning locative case

a. o czarwnic-ach

about witch-NVIR.LOC

'about witch'

b. o pięc-iu straszn-ych czarownic-ach

about five-GEN/LOC/DAT scary-NVIR.GEN/LOC witch-NVIR.LOC

'about five scary witches'

Preposition assigning dative case

a. wbrew czarownic-om

against witch-NVIR.DAT

'against witches'

b. wbrew pięc-iu straszn-ym czarownic-om

against five-GEN/LOC/DAT scary-NVIR.DAT witch-NVIR.DAT

'against five scary witches'

In examples (43)-(45), we see that there is no genitive marking on the quantified noun phrase in the NQP. Instead, it is marked with lexical case, based on the choice of preposition. ${ }^{14}$ However, in other quantificational contexts that also assign genitive, such as (pseudo-)partitives, the genitive persists in the very same contexts where it "disappeared" in (43)-(45):
Partitive construction
wiadr-o wod-y
bucket(N)-NOM water(F)-GEN
'a bucket of water'

\footnotetext{
${ }^{13}$ To be precise, in the NQP example in (42)b), the genitive on the numeral comes from the preposition. However, as a reviewer rightly points out, the genitive marking on the quantified noun phrase may be assigned either by that preposition (as in (42)a)) or have the same source as the quantificational genitive that is found even in the absence of any preposition. Morphologically, the prepositional genitive and the quantificational genitive are indistinct. Both options are in line with the proposal presented here.

${ }^{14}$ The reader may have noticed that I have not provided any instances of a preposition assigning (what looks like) accusative. Such case assignment configurations exist but discussing them at this stage would complicate the picture. In the next section, I will return to these cases, and argue that they provide interesting insight into the structure of NQPs and the kind of accusative case we are dealing with.
} 
(47)

\author{
Partitive construction in instrumental case \\ $\mathrm{z}$ wiadr-em wod-y \\ with bucket(N)-INS water(F)-GEN \\ 'with a bucket of water'
}

(48) Partitive construction in genitive case

dla wiadr-a wod-y
for bucket(N)-GEN water(F)-GEN
'for a bucket of water'

(49)

Partitive construction in locative case

o wiadrz-e wod-y

about bucket(N)-DAT/LOC water(F)-GEN

'about a bucket of water'

(50) Partitive construction in dative case

$\mathrm{ku}$ wiadr-u wod-y

towards bucket(N)-DAT/LOC water(F)-GEN

'towards a bucket of water'

None of the lexically-assigned cases "override" the genitive on the embedded noun in a (pseudo-)partitive construction. Therefore, the genitive in NQPs and the genitive in (pseudo-)partitive construction must differ somehow. Comparing several Slavic languages, Franks (1995) explains this difference in terms of the distinction between structural case (e.g. Russian) and lexical case (e.g. Serbo-Croatian). ${ }^{15} \mathrm{He}$ assumes that lexical/inherent case is assigned at D-Structure while structural case is assigned at S-Structure. Once a noun phrase is case marked at D-Structure, it cannot receive any other case at S-Structure. Therefore, the relative timing of different case assignments determines the surface morphology. Below, I will adopt an extension of a recent analysis of genitive in Finnish numeral-noun constructions that also relies on timing, but without reference to D- and S-structures (Norris 2018). Finally, I will show why an alternative analysis of genitive in Russian NQEs (Bailyn 2004) is incompatible with Polish NQEs.

4.1.1 Structural case assignment vs. concord spreading of case (Norris 2018)

Norris (2018) analyzes a pattern of overridable partitive case in Finnish NQEs which is very similar to the overridable genitive discussed here: ${ }^{16}$

\author{
Finnish NQP in a non-oblique context (Brattico 2010) \\ ne kaksi pien-tä auto-a \\ DEM.NOM two.NOM small-PAR car-PAR \\ 'those two small cars'
}

\footnotetext{
${ }^{15}$ Although I will not delve into this issue as it regards Polish, let me briefly explain why ascertaining the structural vs. lexical/inherent status of genitive case on the quantified NP in Slavic is very difficult. Standard diagnostics such as (i) case-preservation under A-movement, (ii) presence of nominative objects in ECM constructions, and (iii) theta-relatedness (Woolford 2006), cannot be applied here for structure-/language-specific reasons. First, genitive-marked quantified NPs inside an NQP cannot be A-moved (raised or passivized) to the exclusion of the rest of the NQP, i.e., the numeral. Second, Polish does not have any ECM constructions (Przepiórkowski 2004). Finally, it is hard to conceptualize a unique theta-role that is borne by the quantified NP (again, to the exclusion of the rest of the NQP), or how such a role would be assigned. Thus, the interaction effects discussed in the main text appear to be the only diagnostic available.

${ }^{16}$ To be precise, Estonian and Finnish distinguish between genitive and partitive case, and the case on the quantified nouns in NQEs is in fact partitive. There is no such distinction in Polish, but that has no influence on the proposed analyses.
} 
Finnish NQP in an oblique context (Brattico 2010)

a. nii-ssä kolme-ssa piene-ssä talo-ssa DEM-INE three-INE small-INE house-INE 'in those three small houses'

b. *nii-ssä kolme-ssa pien-tä talo-a DEM-INE three-INE small-PAR house-PAR 'in those three small houses'

In the examples above we see that in Finnish the numeral (N1) precedes the quantified noun (N2), just like in Polish. Example (51) shows that when the numeral (N1) is marked with nominative, the quantified noun (N2) takes partitive case. However, when the numeral is marked with some lexical case like the inessive, the quantified noun must also be inessive (52a) and not partitive (52b). Norris argues that in non-oblique environments, partitive on the quantified noun is assigned whenever that quantified noun (N2) is a complement of the other noun (N1) but has not received any (other) case yet. ${ }^{17}$ But when the higher embedding noun (N1) is marked with a case that is lexical, that case spreads via a concord relation-spreading of a feature throughout a constituent whenever the concord conditions are met. Thus, the derivation of case assignment to Finnish NQPs in structural-case environments is as follows: the caseless complement (N2) receives partitive; later, other structural case (e.g. nominative) is assigned to the higher noun (N1) via a typical case licensing mechanism as shown in (53):

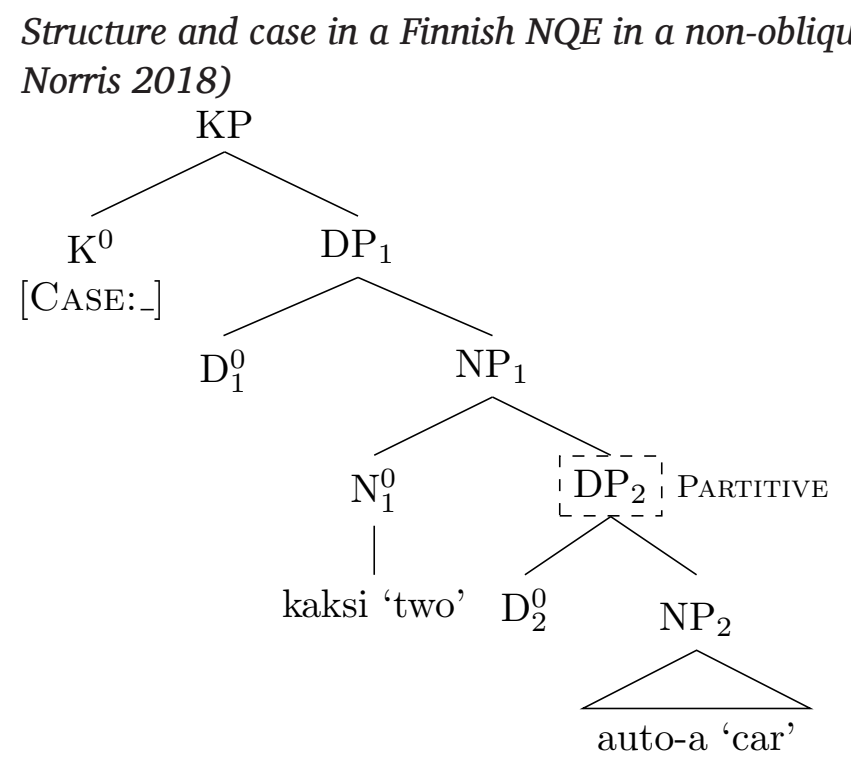

Alternatively, if lexical case is assigned to a higher noun (N1), that case spreads downwards onto the quantified noun (N2) as shown in (54):

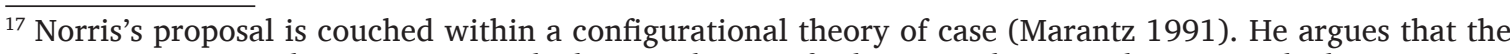
partitive in Finnish NQEs is unmarked case. This is a fairly unusual approach to unmarked case assignment; Marantz treats unmarked case as an operation that applies to all caseless DPs in a given domain, while Norris's algorithm refers to a specific structural condition, i.e., being the complement of a particular head. This modification allows the algorithm to assign unmarked case to nominal phrases of any size-i.e., DPs, NumPs, or NPs-as long as they meet the structural-position requirement. I choose to refer to the Polish counterpart of this case as structural, but I remain agnostic as to whether it is assigned configurationally.
} 
Structure and case in a Finnish NQE in an oblique context (adapted from Norris 2018)

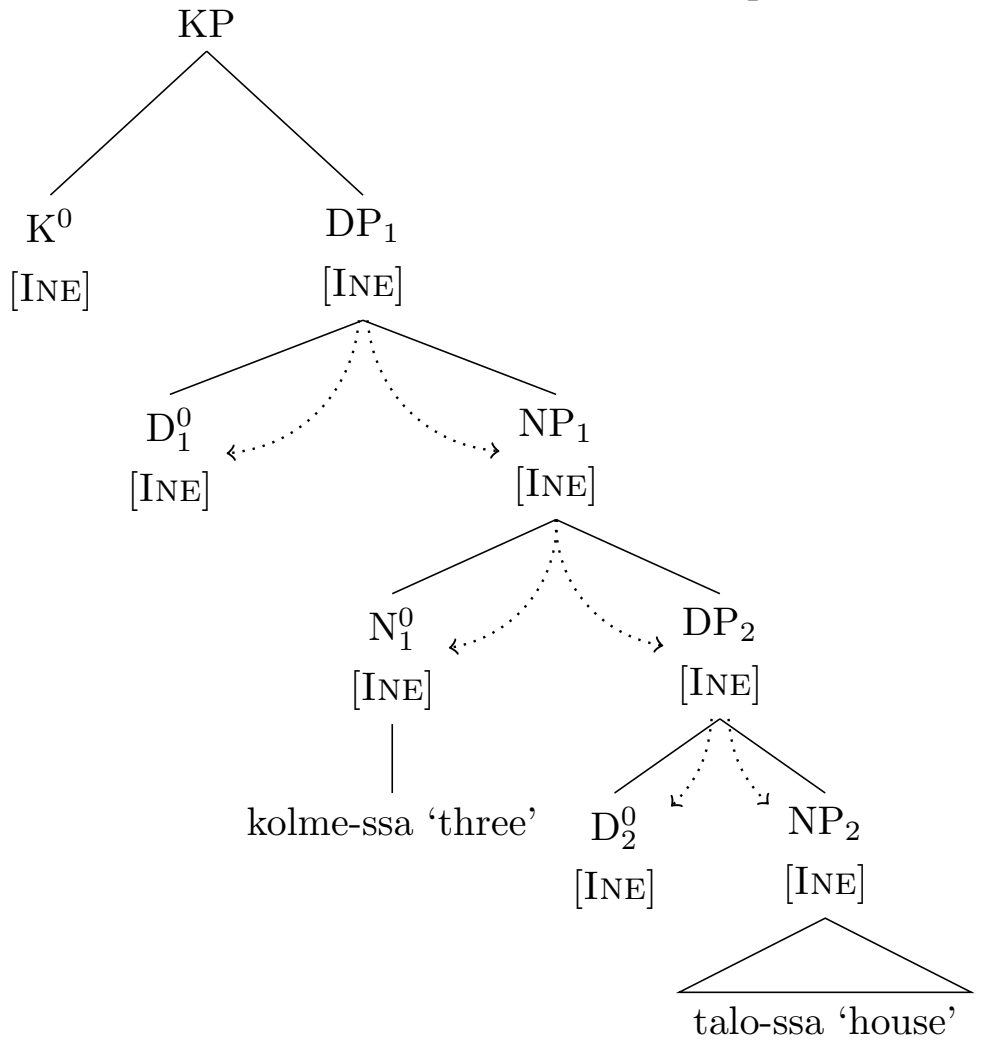

Let us now turn to Polish, and to the question of whether the genitive we find there can be analyzed on a par with these instances of partitive in Finnish. First, this particular analysis relies on Finnish numerals being nouns. I have shown that Polish NQPa do not behave in a manner typical of noun phrases (see section 3.2, and in particular (13)-(15)). Second, even if Polish numerals carried some nominal feature that this unmarked genitive were associated with, it is still the case that Polish numerals are not heads. I have argued (in section 3) that the quantified noun is a complement of a functional head, not of the numeral itself. Although Norris explicitly frames this unmarked partitive as a case assigned to the complement of nouns, he also notes that this proposal should work equally well for other types of structures that have been proposed in the literature on NQEs (Norris 2018: fn. 7: 530).

In sum, in order to fit the Polish data, Norris's proposal should be reformulated as follows:

Structural genitive

Assign structural genitive to a noun that is a complement of $\mathrm{NQ}^{0}$ and does not have case value when the NQP extended projection is complete

Since genitive is not a general default case for nominals in Polish (nor is partitive in Finnish), the conditions on genitive assignment need to be stated more precisely than just "assign genitive to any caseless noun." Nowhere else in Polish do we see default genitive-for example, citation forms and hanging topics are always nominative. Therefore, the domain in which this case assignment mechanism applies is crucial. Furthermore, we see from the Polish (pseudo-)partitive examples in (46)-(50) that we need another way of assigning genitive in Polish-one that applies in (pseudo-)partitives, and occurs regardless 
of the presence of another lexical case. ${ }^{18}$ I will now spell out the steps of the derivations for different constructions.

The derivation for Polish NQP subjects proceeds as follows. At the point when the NQP projection has just been completed, neither NQP nor NP/DP bears any case yet. The structural genitive case mechanism applies at this point, and the quantified noun phrase is assigned genitive. (Whether NQP later receives expected nominative case by virtue of being in a canonical subject position will be the topic of Section 5.) Conversely, the derivation for Polish NQPs in the complement position of a preposition proceeds differently. When the extended projection that the NQP is part of has been completed, the case of the NQP has already been valued by the lexical case of the preposition, which then spreads via concord onto the embedded quantified noun phrase. No structural genitive case assignment mechanism can take place, because the quantified noun phrase already bears case. Finally, I assume that unlike NQPs, true partitive constructions in Polish-as in examples (46)-(50)—involve a partitive projection, which I will label PartP. The derivation for Polish PartPs in any position in a clause starts with the quantified NP/DP being assigned inherent genitive from Part ${ }^{0}$. Further structure-building does not change the case marking on the quantified NP/DP, even if upon completion of PartP there is another lexical case assigned to the entire PartP (e.g. by a preposition).

Norris's analysis is the only existing analysis of the alternation between genitive and other lexical cases on the quantified noun that fits the structure of Polish NQPs. This raises the question of why a language would need a case-assignment mechanism that is restricted to NQPs. Kornfilt and Preminger (2015) propose that nominative amounts to a lack of case in the TP domain, while genitive is the lack of case in the nominal domain. If we adopt this view, then genitive being restricted to NQPs is a red herring-NQPs might be the only available nominal domain where there is no case on a quantified noun (recall that Part $^{0}$ is assumed to be a case-assigner).

In the following section, I will briefly sketch another proposal for capturing the same alternation. I argue that this alternative requires a greater number of non-trivial assumptions than the Norris-style account just outlined.

\subsubsection{Variability in position of the numeral (Bailyn's analysis)}

Bailyn (2004) derives the behavior of genitive on the quantified noun phrase in Russian by means of variation in the overtness of a $\mathrm{Q}^{0}$ head. In non-oblique positions, $\mathrm{Q}^{0}$ is empty, and only then can it assign genitive to the quantified noun; the numeral is a phrase located in the specifier of QP:

Bailyn's analysis of structure and case in an NQE in a non-oblique position in Russian

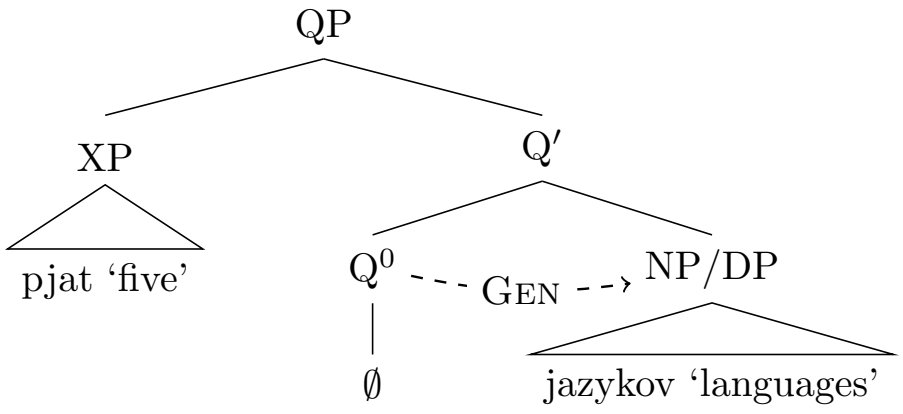

\footnotetext{
${ }^{18}$ Norris (2018: 553-556) observes the difference between 'overridable' partitive in NQEs and 'non-overridable' partitive in partitive constructions in Finnish as well.
} 
In oblique positions, on the other hand, $\mathrm{Q}^{0}$ is overtly filled by a numeral, which, unlike null $\mathrm{Q}^{0}$, is unable to assign genitive:

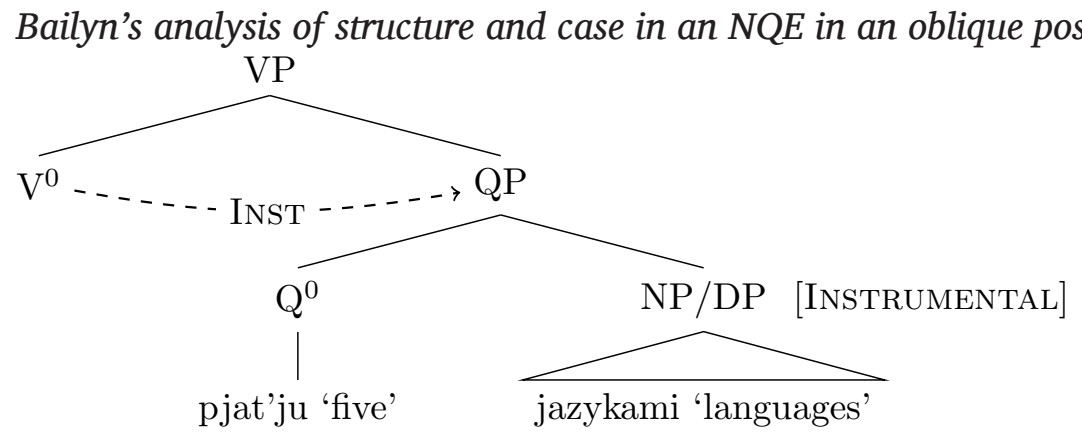

On this proposal, then, the position of the numeral varies: in non-oblique environments the numeral is in Spec- $Q^{0}$, and in oblique environments the numeral is the head $\mathrm{Q}^{0}$ itself. The $\mathrm{Q}^{0}$ head can assign genitive only when it is null. Bailyn points out that this analysis finds analogy in other constructions where the overtness of a head has an influence on case assignment in Russian, such as the predicate instrumental construction (Bailyn 2001: 3-4):

(58) Russian primary predicate:

Ivan durak/*durakom.

Ivan fool.NOM/fool.INS

'Ivan is a fool.'

(59) Russian secondary predicate argument:

Ivan kažetsja *durak/durakom.

Ivan seems fool.NOM/fool.INS

'Ivan seem to be a fool.'

In sum, Bailyn's proposal attributes genitive assignment to the presence of a null head. Oblique environments require that the numeral fill this head position.

Conceptually, it may be seen as problematic that, under Bailyn's analysis, numerals are sometimes heads and sometimes phrases. More importantly, however, I argued in section 3.4 that numerals in Polish are (invariably) phrasal. Although all the examples in that section presented non-oblique environments, that was a purely expository choice; the tests in question yield the same results in oblique environments. For example, coordination with a simple numeral in a dative context is acceptable, just as it is in the nominative context in (36):

$N Q P$ with coś in a dative context

ku pięć-iu czy coś czarownic-om

towards five-DAT or something witch-NVIR.DAT

'towards five or so witches'

Therefore, adopting Bailyn's analysis would require an additional account of why numerals behave like phrases but can nevertheless compete with null $\mathrm{Q}^{0}$ for the $\mathrm{Q}^{0}$ position.

\subsubsection{Summary of the section}

In this section, I have shown how at least one existing analysis of genitive on quantified noun phrases - the one put forth by Norris (2018) - fits the structure of Polish NQPs. In the following section, I will show that the numeral surfaces with accusative, which also calls for an explanation. I will then discuss several possible sources for this accusative marking on the numeral. 


\section{Accusative on the numeral}

In section 3.3, I showed that apparent subject NQPs in Polish do indeed pass the diagnostics for subjecthood. Polish subjects are usually marked with nominative; in rare cases of experiencer subjects, they are marked with dative, yielding non-agreeing subjects. In the examples I have been considering, NQPs are not dative experiencers. Therefore, they should in principle be nominative, like other subjects. However, this is not the case. Case morphology on the numeral itself is not very telling, but nominative-marked modifiers (e.g. adjectives and demonstratives) are unavailable with NQPs (Przepiórkowski 1996; Franks 2002; Rutkowski 2009; Miechowicz-Mathiasen 2012):

Nominative modifier with a virile noun

$$
\mathrm{Ci} \quad \text { czarodziej-e przyjecha-1-i. }
$$

DEM.VIR.NOM wizard-VIR.NOM arrive-PST-VIR

'These wizards arrived.'

$$
\begin{aligned}
& \text { Nominative modifier with an NQP with a virile noun } \\
& { }^{*} \mathrm{Ci} \text { pięc-iu czarodziej-e/-ów } \\
& \text { DEM.VIR.NOM five wizard-VIR.NOM/GEN } \\
& \text { Intended: 'These five wizards arrived.' }
\end{aligned}
$$

Example (62) shows that a nominative demonstrative is ungrammatical with an NQP subject, in contrast with regular nominal subjects, as shown in (61). This restriction, at least at first glance, does not seem to hold with non-virile NQPs:

Demonstrative modifying the non-virile noun

$\mathrm{Te} \quad$ czarownic-e przyjecha-ł-y.

DEM.NVIR.NOM/ACC witch-NVIR.NOM/ACC arrive-PST-NVIR

'These five witches arrived.'

(64) Demonstrative modifying the non-virile numeral/NQE

Te pięć czarownic- $\varnothing$ przyjecha-ł-o.

DEM.NVIR.NOM/ACC five witch-NVIR.GEN arrive-PST-3SG.N

'These five witches arrived.'

It seems that the non-virile NQE can take a nominative-marked demonstrative in (64)the exact same form that is also available for regular nominal subjects, as in (63). One approach is to propose different case for virile vs. non-virile NQEs in the subject position, along the lines of Differential Subject Marking (Silverstein 1976; Aissen 2003: 472-474; Malchukov 2006): overt morphological marking on a subset of nominal subjects based on a particular property (e.g. definiteness or animacy). An alternative approach, already suggested in the gloss of (64), is that nominative-accusative case syncretism obscures the underlying pattern: the modifier could in principle bear either of these cases underlyingly. Turning back to virile NQPs, we see that an accusative demonstrative is indeed the only acceptable form:

Accusative modifier with NQP with a virile noun ${ }^{19}$

Tych pięc-iu czarodziej-ów przyjecha-ł-o.

DEM.VIR.ACC/GEN five-VIR wizard-VIR.GEN arrive-PST-3SG.N

'These five wizards arrived.'

\footnotetext{
$\overline{{ }^{19} \text { For more details }}$ about syncretism, see the Appendix.
} 
In totality, the paradigm in (62)-(65) suggests that the accusative form is always available for any grammatical gender, and the apparent availability of nominative or genitive is an illusion caused by morphological syncretism.

Before turning to the potential sources of this accusative marking, let me complete the pattern of available modifiers in NQPs. Alongside the syncretic accusative-genitive form of the modifier in the virile NQP in (65), a non-syncretic genitive form of the modifier is also available in non-virile NQPs:

$$
\begin{aligned}
& \text { Genitive modifier with NQP with a non-virile noun } \\
& \text { Tych pięć czarownic- } \varnothing \text { przyjecha-ł-o. } \\
& \text { DEM.NVIR.GEN five witch-NVIR.GEN arrive-PST-3SG.N } \\
& \text { 'These five witches arrived.' }
\end{aligned}
$$

The word order suggests that this genitive modifier is associated with the lower, quantified noun-already shown to be marked with genitive. While the genitive modifier can stay low next to the noun (67b), or be fronted (66), the accusative form must precede the numeral; compare (64), above, with the ungrammatical (67a):

(67) Demonstratives between the numeral and the noun
a. *Pięć te czarownic- $\varnothing$ przyjecha-ł-o.
five DEM.ACC witch-NVIR.GEN arrive-PST-3SG.N
'Five of these witches arrived.' (partitive interpretation)
b. Pięć tych czarownic- $\varnothing$ przyjecha-ł-o.
five DEM.GEN witch-NVIR.GEN arrive-PST-3SG.N
'Five of these witches arrived.' (partitive interpretation)

If the accusative modifier targets the numeral to the exclusion of the quantified noun, we expect that not all adjectives could felicitously occupy that position, due to their meaning. For example, the numeral itself cannot by modified by an adjective like 'scary' or 'pretty' (cf. '\#pretty five', '\#scary five'). This prediction is borne out:

(68) Modifying adjective in accusative

?\#Straszne pięć czarownic- $\varnothing$ przyjechał-o.

scary-ACC five witch-NVIR.GEN arrive-PST-3SG.N

Intended: 'Five scary witches arrived.'/ 'Scary five witches arrived.'

(69) Modifying adjective in genitive

Straszn-ych pięć czarownic- $\varnothing$ przyjechał-o.

scary-GEN five witch-NVIR.GEN arrive-PST-3SG.N

'Five scary witches arrived.'

The contrast between (68) and (69) above shows that a modifier 'scary' is felicitous only when it is marked with a genitive, i.e., it modifies the quantified noun (despite being fronted). On the other hand, when the same adjective is accusative-marked-i.e., it modifies just the numeral-the sentence becomes infelicitous.

Finally, there are other adjectives whose interpretation distinguishes numeral and nominal arguments, such as niecałe 'not entire(ly)/not full':

(70) Adjective in accusative modifying the numeral or NQP

Zosta-ł-o niecał-e pięćdziesiąt butelek- $\varnothing$ win-a.

leave-PST-3SG.N not.entire-ACC fifty bottle-NVIR.GEN wine-GEN

'There are almost fifty bottles of wine left.' 

Modifying adjective in genitive modifying the noun
Zosta-ł-o
pięćdziesiąt niecał-ych
butelek- $\varnothing$
win-a.
leave-PST-3SG.N fifty
not.entire-GEN bottle-NVIR.GEN wine-GEN
'There are fifty non-full bottles of wine left.'

The accusative form of the adjective 'not entire' yields an interpretation involving number modification, i.e., 'not the entire $50 \sim$ less than 50.' The genitive form of the same adjective yields the reading of volume modification, i.e., 'not entire bottles $\sim$ partially empty bottles. ${ }^{20,21}$

My own data elicitation suggests that speakers avoid interpreting declinable prequantifiers as modifying just the numeral. ${ }^{22}$ Polish speakers strongly prefer using indeclinable adverbials like prawie or niemalże 'almost'. This itself might suggest that the NmrP can only be modified by an indeclinable adverb, whereas accusative modifiers modify the entire NQP. However, speakers accept examples with accusative prequantifiers like (70) in the right pragmatic contexts where the prequantifier clearly modifies the numerical phrase to the exclusion of the quantified noun as in 'He lived not entire 50 years' or 'Not entire 50 people arrived'.

Thus, the availability of two forms of demonstratives in an NQP, accusative and genitive, reflects different underlying structures. Crucial for the current discussion is the fact that there is some syntactic constituent marked with accusative (to which the accusative version of the modifier presumably attaches), and the numeral is a likely target. There is no obvious source for this accusative, such as a verb or an overt preposition. I will now suggest that positing a null preposition-although not without its flaws-is the best analytical option, both empirically and theoretically.

\subsection{Accusative licensed by a preposition}

In this section, I will argue that the accusative on 5+ numerals in Polish NQPs is licensed by a silent preposition. A similar analysis has already been proposed by MiechowiczMathiasen (2012). The main difference between her analysis and the present one is due to the structure argued for above, where the numeral is a phrase and not the head of NQP. In 5.1.1, I will first discuss the relevant aspects of the prepositional system in Polish, and then show how such system allows positing a null preposition in NQPs. In 5.1.2, I compare two alternative loci for this putative null preposition.

\subsubsection{The Polish prepositional system}

Polish prepositions form a fairly complex system. They idiosyncratically assign different lexical cases to their complements.

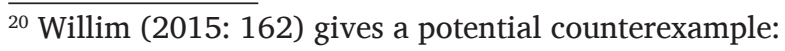

(i) niecał-ych pięćdziesiąt pełn-ych butelek wina not.entire-GEN fifty entire-GEN bottle-NVIR.GEN wine-GEN 'not entire fifty full bottles of wine'

However, according to the acceptability judgments of several native speakers I consulted, (i) is not possible. As suggested by a reviewer, to the extent that the example above is acceptable, this might be an effect of some version of agreement attraction, rather than actual grammaticality of the string under the intended interpretation. A brief survey on 10 native speakers showed a clear contrast when the quantified noun phrase is one whose meaning cannot be modified by 'not entire':

(ii) niecał-*ych/e pięćdziesiąt osób not.entire-*GEN/ACC fifty people-GEN 'not entire fifty people'

${ }^{21}$ The availability of genitive modifiers, both demonstratives and adjectives, confirms that the quantified nominal is a full noun phrase-rather than a reduced phrase or a bare noun (cf. Norris 2018 on Estonian).

${ }^{22} \mathrm{~A}$ reviewer confirms this observation. 
(72) Polish prepositions categorized by case they assign

a. Genitive-assigning prepositions: bez 'without', do 'to', od 'from'

b. Dative-assigning prepositions: $w b r e w$ 'against', przeciw 'against'

c. Locative-assigning prepositions: $o$ 'about', $n a$ 'on', $w$ 'in'

d. Instrumental-assigning prepositions: $z$ 'with', przed 'in front of', pod 'under'

It is not trivial to draw generalizations about the semantic grouping of these prepositions and their alignment with case morphology. However, there is a subset of locative- and instrumental-assigning prepositions that denote a relation to a static location-e.g. $n a_{\text {Loc }}$ 'on' and $\operatorname{pod}_{\mathrm{INS}}$ 'under'. This group of prepositions, when denoting a path/motion towards the object instead of a static location, assigns accusative rather than locative or instrumental case it would otherwise assign:

(73) Preposition with a stative location

siedzie-ć na miotl-e

sit.IPFV-INF on broom(F)-LOC

'to be sitting on a broom'

(74) Preposition with a goal

wej-ść na miotł-ę

enter.PFV-INF on broom(F)-ACC

'to step on(to) a broom'

(75) Preposition with a static location

siedzie-ć pod miotł-ą

sit.IPFV-INF under broom(F)-INS

'to be sitting under a broom'

(76) Preposition with a goal

wej-ść pod miotł-ę

enter.PFV-INF under broom(F)-ACC

'to step under a broom'

Furthermore, the same prepositions can also be idiosyncratically selected by some verbs, without the meaning of a static location. For example:

(77) Verb selecting for an accusative-assigning na 'on' preposition

czeka-ć na czarownic-e

wait-INF on witch-NVIR.ACC

'to wait for witches'

This prepositional accusative is present even in the context of negation. ${ }^{23}$ This is noteworthy because negation in Polish obligatorily turns a typical accusative direct object into genitive:

Genitive of negation in Polish

a. Widzia-ł-am czarownic-ę. see-PST-1SG.F witch-F.ACC 'I saw a witch.'

\footnotetext{
${ }^{23} \mathrm{I}$ am grateful to a reviewer for pointing this out.
} 
b. Nie widzia-ł-am czarownic*-ę/-y.

NEG see-PST-1SG.F witch-*F.ACC /-F.GEN

'I did not see a witch.'

However, genitive of negation does not apply to objects of prepositions, even if they are marked with accusative:

(79) Negation and prepositional accusative

Nie czeka-ł-am na czarownic-ę/*-y.

NEG wait-PST-1SG.F on witch-F.ACC/*-F.GEN

'I didn't wait for a witch.'

These data show that, in general, there are accusative-assigning prepositions in Polish. Given the general availability of accusative-assigning prepositions, I propose that the accusative in NQEs also comes from a preposition, albeit one that is phonologically null.

There is a potential counterargument to positing a null preposition in this context. In contrast to the behavior of the accusative-assigning prepositions shown above, genitive of negation does appear on the numeral in an NQP:

\section{Negation of object NQPS}

a. Widzia-ł-am pięć czarownic- $\varnothing$. see-PST-1SG.F five witch-NVIR.GEN 'I saw five witches.'

b. Nie widzia-1-am pięc*(-iu) czarownic- $\varnothing$. NEG see-PST-1SG.F five-GEN witch-NVIR.GEN 'I didn't see five witches.'

Miechowicz-Mathiasen (2012) argues that the null preposition in an NQP is defective/light. More precisely, it does not project a PP, but m-merges with the head it immediately c-commands and selects for:

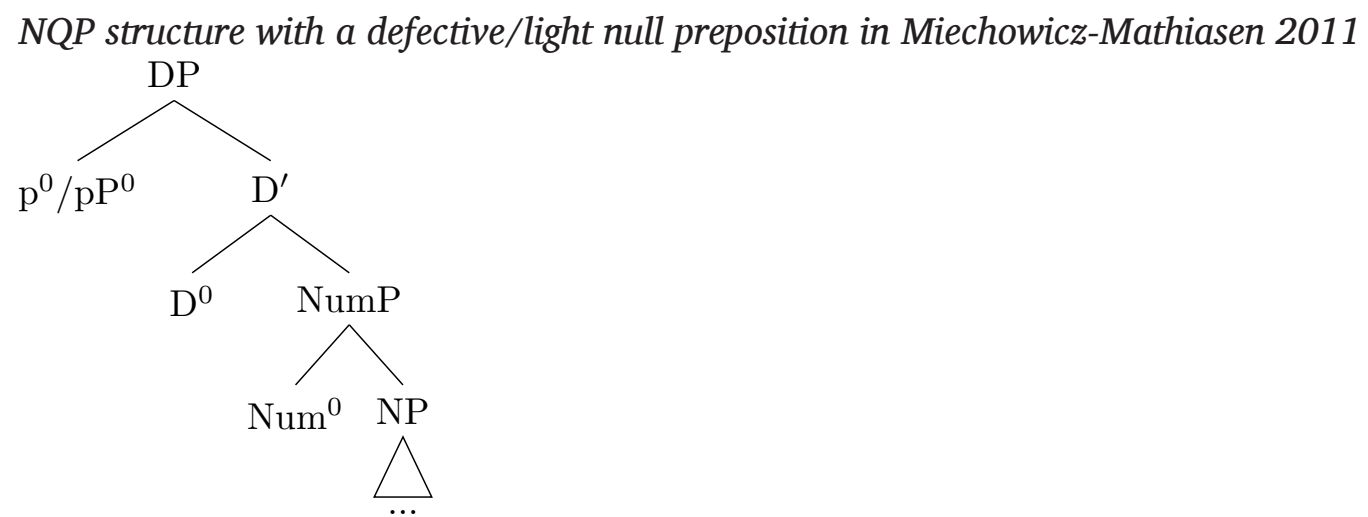

Miechowicz-Mathiasen discusses similarities between such null prepositions and overt adnumeral operators like okoto, z 'around, approximately' and ponad 'over', which are also transparent for the case-marking of their complement, and for theta-role assignment to it. This could be one potential explanation of why genitive of negation overrides the accusative that this null preposition typically assigns in NQPs, but does not override the accusative that overt prepositions assign.

Furthermore, while bona fide PPs can show up adnominally-as unselected modifiers of a noun phrase-NQPs do not seem to have the same syntactic and semantic distribution: 
(82) The availability of a PP modifier of an object

Widzia-ł-am czarownic-e z miotł-ami.

see-PST-1SG.F witch-NVIR.ACC with broom-NVIR.INS

'I saw the witches with brooms.'

(83) The unavailability of a numeral phrase/NQP modifier of an object

Widzia-ł-am czarownic-e (*\#pięć mioteł- $\varnothing$ ).

see-PST-1SG.F witch-NVIR.ACC five broom-NVIR.GEN

\#'I saw the witches five brooms.'

This apparent problem for the analysis of prepositional accusative in NQPs can be addressed in the following two ways. First, there are some PPs with overt preposition, e.g., denoting path/motion like the ones shown in (74) and (76), that also cannot modify noun phrases. It remains to be explained why some PPs serve as modifiers and others do not. Furthermore, this apparent contrast in distribution is not an issue if we posit that the $\mathrm{NmrP}$ is the complement of the null preposition rather than the entire NQP. In the following section, I discuss the two possible positions.

\subsubsection{The position of the null preposition in NQPs}

If an NQP includes a null preposition, we need to address the position of such a preposition in the structure. Given the structure of NQPs I have proposed, this null preposition could take either the entire NQP (84) as its complement, or just the NmrP (85):

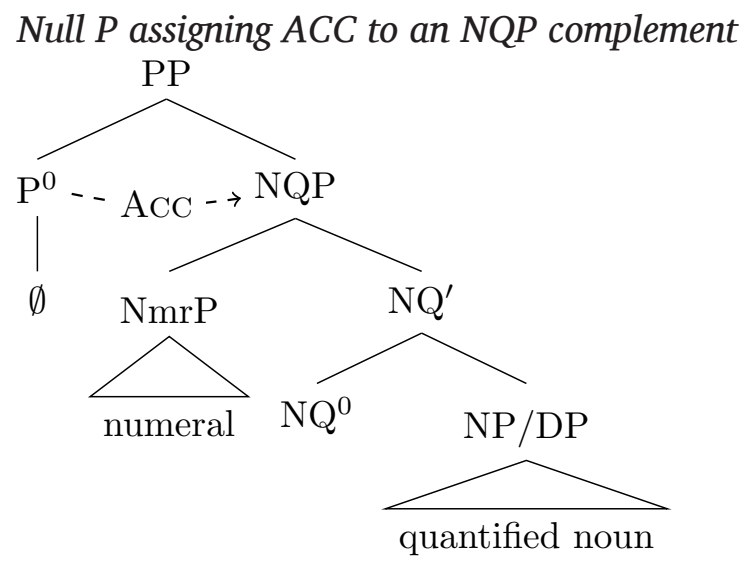

(85)

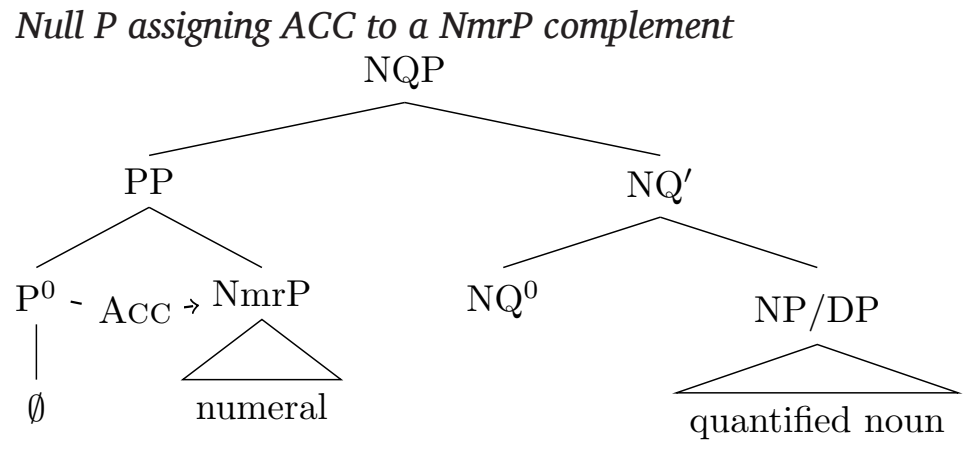

The first hypothesis, involving a PP dominating the entire NQP, is immediately challenged by the facts presented in section 4.1: all prepositions assign lexical case that overrides the case within an NQP. Here, an accusative-assigning null $\mathrm{P}^{0}$ seems to "reach" as far as NmrP, but not into the quantified noun. We saw before that bona fide overt prepositions do impose their lexical case on the entire NQP, including the quantified noun. 
The second hypothesis, involving a $\mathrm{P}^{0}$ whose complement is only NmrP, avoids the above problem. If prepositions can only assign case in their c-command domain, this correctly predicts that accusative would not reach the quantified noun. However, we then need to explain how other overt prepositions, such as the ones in examples (43)-(45), are able to override the accusative assigned by this null preposition. This would create a scenario we might describe as a complex preposition, involving two different prepositions, where the higher preposition determines the case on the nominal complement. There are a number of complex prepositions in Polish, most of which are lexicalized $\mathrm{P}+\mathrm{N}$ combinations. There is only one pattern of complex prepositions that can be decomposed into two simplex prepositions. The higher preposition $z$ 'from', which on its own assigns genitive, combines with a handful of location-denoting prepositions such as pod 'under', nad 'above', przed 'in front of', all of which alternate between instrumental and accusative, as shown in (75) and (76). The complex preposition e.g. $z+$ nad has a derived meaning 'from above', and uniformly assigns genitive:

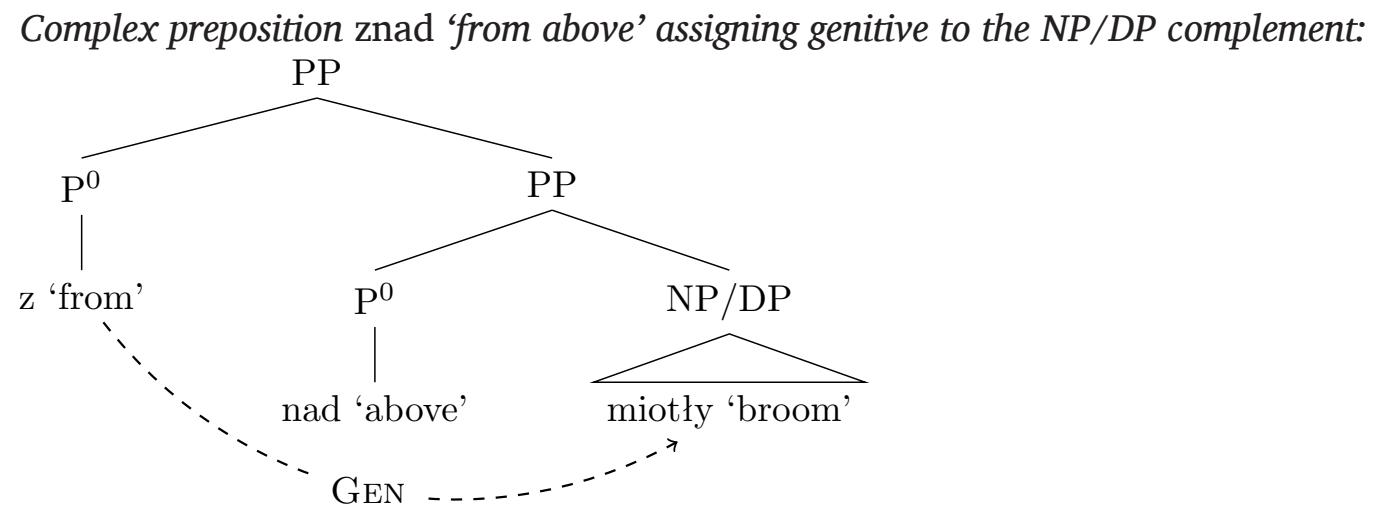

'from above the broom'

If we adopt the structure in (85), we can argue that a null preposition assigns accusative to the numeral without this accusative case extending to the quantified noun, and, at the same time, predict that this accusative would be overridden by a higher instance of $\mathrm{P}^{0}$, just as the instrumental/accusative in (86) is.

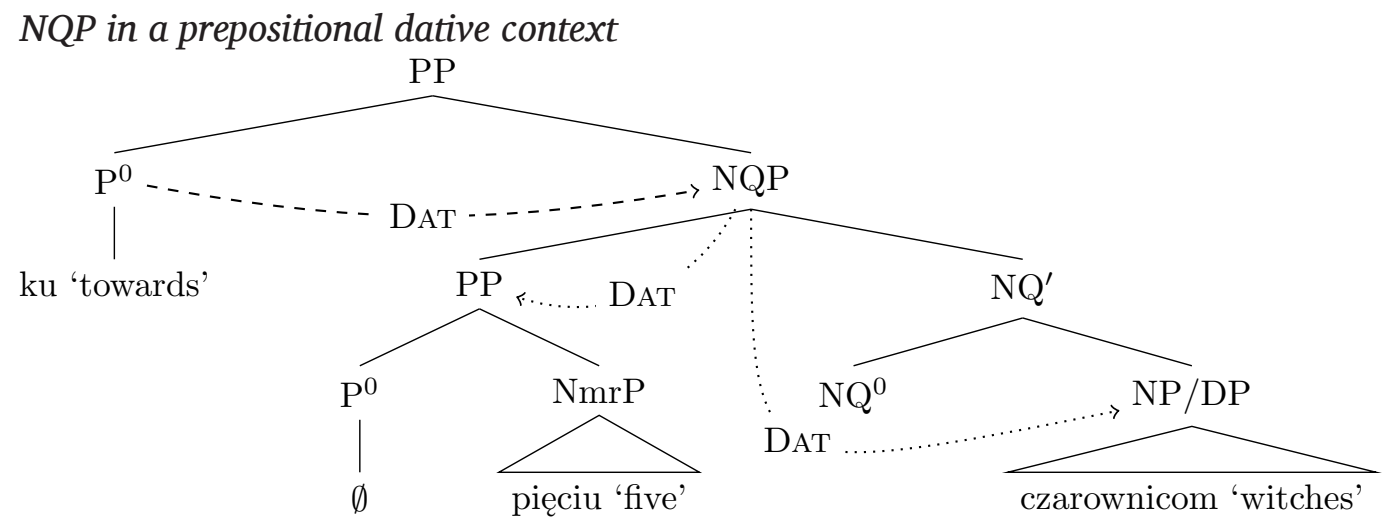

'towards five witches'

There are further parallels between overt and null accusative-assigning prepositions. Accusative is found with prepositions such as one shown in (77) and with a subset of goaldenoting prepositions, such as those shown in (74) and (76) above. These prepositions should be able to take an NQP as a complement just like any other preposition would. But just like the proposed null accusative $\mathrm{P}^{0}$, the overt accusative assigned by these prepositions does not spread all the way to the quantified noun: 
Preposition with a stative location NQP

siedzie-ć na pięci-u miotł-ach/*mioteł- $\varnothing$

sit.IPFV-INF on five-LOC broom-NVIR.LOC/broom-NVIR.GEN

'to be sitting on five brooms'

\author{
Preposition with a goal NQP \\ wej-ść na pięć mioteł- $\varnothing / *$ miotł-y \\ enter.PFV-INF on five broom-NVIR.GEN/broom-NVIR.ACC \\ 'to step on(to) five brooms'
}

Example (88) shows an overt preposition taking an NQP as its complement and assigning locative all the way down to the quantified noun. But in (89), where the same preposition designates a goal, and therefore assigns accusative (see (74) above), this accusative is assigned to the numeral (morphological syncretisms notwithstanding; see the beginning of Section 5)-but it is not assigned to the quantified noun phrase. This noun is still marked with genitive. This behavior demands explanation one way or another; however, whatever it is that accounts for this "short-range" case assignment by accusative-assigning prepositions could in principle apply to a null preposition as well, therefore removing one obstacle to the hypothesis that this null P takes the entire NQP as its complement (as in (84)). ${ }^{24}$

\title{
5.2 Other proposals
}

I will now briefly mention a number of other options for the source of accusative, and argue that, ultimately, none of these seems to have any advantage-theoretically or empirically-over the null preposition hypothesis outlined above.

\subsubsection{Accusative from $\mathrm{NQ}^{0}$}

If we assume the structure in (37), repeated here for convenience as (90), we could hypothesize that $\mathrm{NQ}^{0}$ not only selects for its numeral-phrase specifier, but also assigns accusative to it:

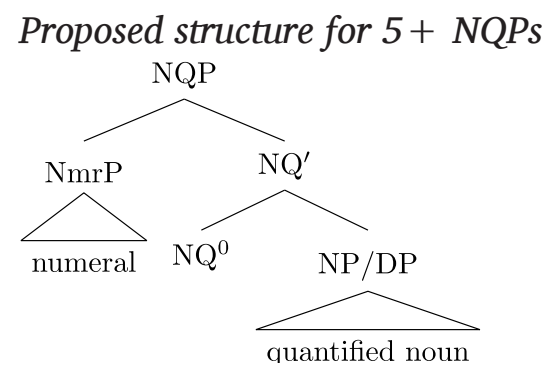

\footnotetext{
${ }^{24}$ Furthermore, if it is true that all NQPs are ultimately PPs, we would like to see if other PPs behave the same, e.g. with respect to subjecthood diagnostics (see section 3.3). Jaworska (1986: 358) claims that PPs can be subjects in Polish:
}

(i) PP in subject position (adapted from Jaworska's 11a)

Po obiedz-ie pasowa-ł-o wszystk-im.

After dinner-LOC suite-PST-3SG.N everyone-DAT

'After dinner suited everyone.'

In (i) po obiedzie 'after dinner' is assumed to be a PP subject. In principle, this example can have three different analyses: as having a PP subject; as an NP/DP subject with a silent nominal head embedding a PP; or as a clause with an expletive subject and adjunct PP (irrelevant structure omitted below):

(ii) Possible analyses of PP arguments
a. $[\mathrm{pp}$ po obiedzie $]$
b. $\quad\left[_{\mathrm{NP}}[\mathrm{PP}\right.$ po obiedzie $]$
$[$ vp pasowa-ł-o wszystkim]
c. $\left[_{\mathrm{TP}}[\mathrm{pP}\right.$ po obiedzie $]\left[_{\mathrm{TP}}\right.$ EXPL $\left[_{\mathrm{vP}}\right.$ pasowa-ł-o wszystkim $\left.\left.]\right]\right]$

I leave it for future work to determine whether these are true PP subjects, but this seems to be a possibility. 
However, by adopting an extension of Norris's (2018) proposal in Section 4.1.1, we have committed to $\mathrm{NQ}^{0}$ ensuring structural genitive on its nominal complement. If $\mathrm{NQ}^{0}$ were specified as assigning both GEN and ACC, then upon merging with the quantified noun NP/DP, NQ ${ }^{0}$ would in principle be able to assign both GEN and ACC to its complement. However, neither ACC nor a stacked combination of ACC and GEN ever show up on the quantified noun. Salvaging an analysis where $\mathrm{NQ}^{0}$ assigns two cases would require that one of the cases is inherent (associated with a theta role) and one is structural (Aldridge 2004; Polinsky 2016). We can reject the idea that either ACC or GEN in an NQP is inherent since both can be overridden by other inherent/lexical cases, as shown in (43)-(45). Finally, assignment of GEN and ACC could be differentiated via ordering or positional diacritics. But it is not clear what advantages such a diacritic-laden analysis has over the analysis in 5.1. In sum, the proposals for double case assignment by the same head face a number of empirical and theoretical challenges that render them undesirable as analyses of the NQP data under discussion. ${ }^{25}$

\subsubsection{Default accusative}

In some languages, e.g. English, accusative has been argued to be a default case marking (Sobin 1997; Schütze 2001; Bošković 2009). For example, it is observed in pronominal conjuncts (even in subject position), as well as in fragment answers:

Pronominal conjuncts in subject position ${ }^{26}$

a. Me and Mary went to the beach.

b. *I and Mary went to the beach.

\section{Fragment answers \\ Q: Who went to the beach? \\ A: $\quad \mathrm{Me} /{ }^{*} \mathrm{I}$.}

However, accusative in Polish does not have the distribution of a default. Coordinated pronouns, fragment answers, as well as previously-mentioned hanging topics and citations forms-none of these surfaces with the accusative case. The only other environment where a nominal is marked with accusative despite not being an object of a verb or an overt preposition is adverbial nominals:

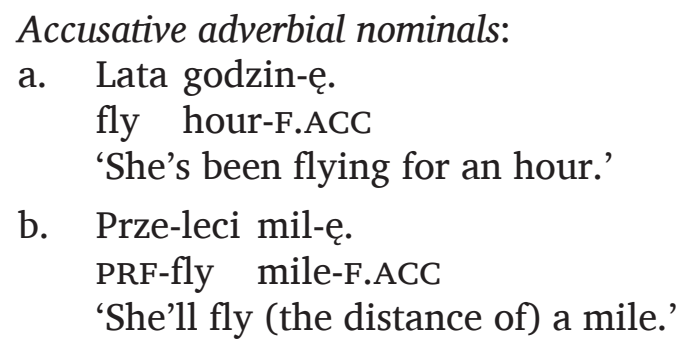

These adverbials have a quantitative meaning, which is a point of similarity with numerals. However, Pereltsvaig (2000) observes that similar expressions in Russian and Finnish interact with aspectual properties of the entire clause. For examples, sentences with this accusative adverbial pass the in-a-minute-test while they do not pass the same test if the

\footnotetext{
${ }^{25}$ I set aside proposals where, in a calculation of a dependent case, the algorithm assigns two dependent cases simultaneously. Such proposal has been put forth for tripartite case system (Baker 2015).

${ }^{26}$ Following Sobin (1997), I use coordination in which the 1SG pronoun is the first conjunct to ensure that the example sits firmly outside the bounds of prescriptive hypercorrection. It is possible that once prescriptive hypercorrection is controlled for, nominative forms are completely absent from all coordinations in English, even those that occupy the finite subject position.
} 
accusative adverbial is absent. This is not the case for numerals, therefore Pereltsvaig's analysis cannot be directly imported here. An alternative analysis restricting accusative to a default marking in some quantitative contexts would therefore need to explain why such adverbs interact with aspect, but numerals do not. I leave this issue for future research.

\subsubsection{Accusative as a result of defective morphology}

Accusative on a numeral could also be a morphological accident, i.e., the paradigm of numerals like $5+$ could simply lack nominative form. It is not immediately clear that a morphological gap in the numeral paradigm in the nominative cell should result in the use of the accusative. If this is an instance of contrast neutralization or impoverishment, these typically lead to the use of less-marked forms, not more-marked ones. At least in Slavic, accusative is typically considered more marked than nominative. Secondly, a morphological gap here should simply lead to ungrammaticality, as it does (arguably) in other cases of inflectional gaps. For example, English dive does not have a participial form for most speakers. Similarly, Russian kočerga 'poker' lacks plural genitive form (Levin 1978). These morphological gaps are ineffable, but this could not be what is going on with Polish numerals-all speakers converge on the same form. Since I do not immediately see how accusative as a morphological gap could account for the facts at hand, I will not pursue this analysis either.

\subsubsection{Accusative as a result of diachronic change}

There is little doubt that numerals in old Polish used to be full-fledged nouns, bearing nominative case, and a series of complex historical changes led to the current state of affairs (Klemensiewicz et al. 1981: 339-343; Miechowicz-Mathiasen 2011). However, even a detailed diachronic account of this change does not preclude the need for a synchronic account. The child acquiring contemporary Polish does not have access to this historical information, after all, and so the question of what her mental representation of NQPs is stands regardless of the historical source of the current pattern.

\subsection{Summary}

In this section, I have shown that modifiers within an NQP can be marked with accusative, and I have suggested that when they bear this case, they modify the numeral. I then proposed that a null preposition is the source of this accusative and discussed how this analysis fits with the structure of NQPs, and within the analysis of structural genitive on a quantified noun adapted from Norris (2018). These three points-the structure of NQPs, the source of genitive on the quantified noun phrase, and the source of the accusative on the numeral-complete the main goals of this paper.

\section{Conclusions}

Numerically-quantified expressions of the $5+$ type have been a long-standing morphosyntactic puzzle in Polish. First, the quantified noun can never be agreed with; when a $5+\mathrm{NQE}$ is the subject, the verbal morphology is uniformly 3SG.N. I argued that NQE subjects occupy the canonical subject position, but fail to agree due to case-discrimination, as Polish verbal agreement targets only nominative goals. Second, case morphology on both the numeral and the quantified noun is unusual. First, when a $5+$ NQE is the subject, its modifiers are not nominative-marked: modifiers of the numerals are accusative-marked and the quantified noun is genitive-marked. Second, when a $5+$ NQE is in an oblique position, both the numeral and the quantified noun display the (matching) case morphology expected for that position. I have argued for an analysis of $5+$ NQEs whereby a null $\mathrm{NQ}^{0}$ takes the quantified noun phrase as its complement, and the numeral phrase as its specifier: 


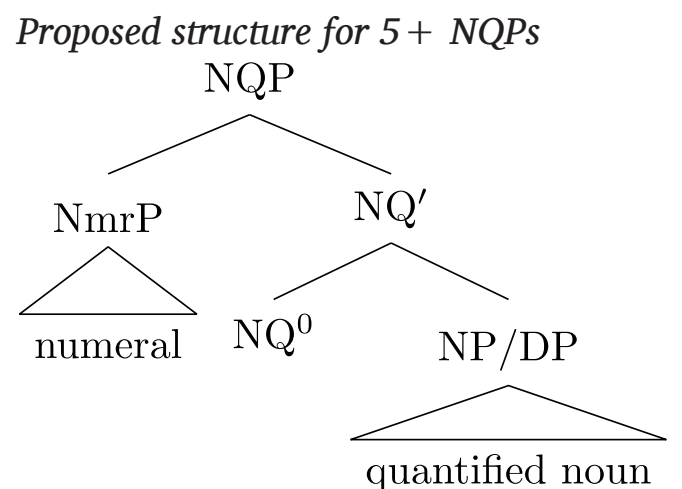

Given this analysis, we were able to use Norris's (2018) proposal where genitive is assigned to a caseless nominal upon completion of its extended projection. The Polish pattern described here lends support to this proposal, and extends it by showing that the proposed case assignment mechanism applies. Next, I argued that the numeral is accusativemarked, and proposed that a null preposition is the source of this case marking. While this account leaves some questions unanswered, I have demonstrated that it is superior to several conceivable alternatives.

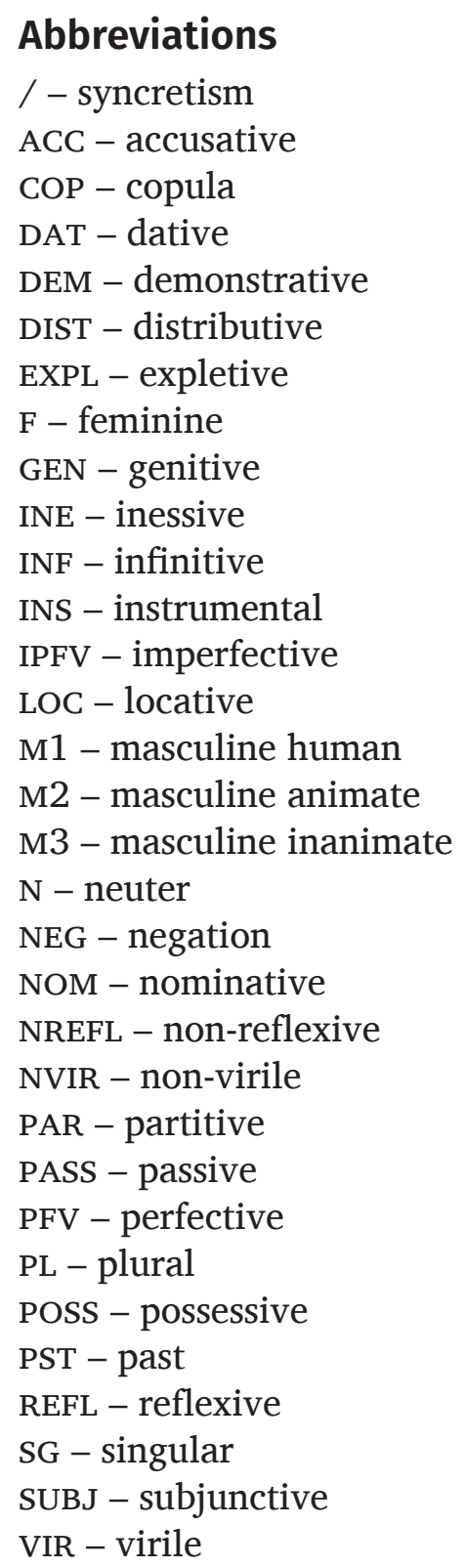




\section{Additional File}

The additional file for this article can be found as follows:

- Appendix. Inflectional paradigm for verbs and $5+$ numerals in Polish. DOI: https://doi.org/10.5334/gjgl.880.s1

\section{Acknowledgements}

I am indebted to many people for their comments and suggestions with this paper: first, Masha Polinsky and Omer Preminger who gave me feedback throughout the entire development of this project, as well as John Bailyn, Howard Lasnik, Ted Levin, Mark Norris, Asya Perseltsvaig, Marta Ruda, Alexander Williams and Ewa Willim for their helpful comments at various stages of this paper, Asia Pietraszko and Małgorzata Łyskawa, as well as friends on Facebook for their Polish judgments. I would also like to thank the anonymous reviewers and editors for their detailed and often challenging feedback that prompted me to rethink some of the issues. All errors are my own.

\section{Competing Interests}

The author has no competing interests to declare.

\section{References}

Aissen, Judith. 2003. Differential object marking: Iconicity vs. economy. Natural Language \& Linguistic Theory 21(3). 435-483. DOI: https://doi.org/10.1023/A:1024109008573

Aldridge, Edith. 2004. Ergativity and word order in Austronesian languages. Ithaca, NY: Cornell University dissertation.

Bailyn, John Frederick. 2001. The syntax of Slavic predicate case. In Gerhard Jäger, Anatoli Strigin, Chris Wilder \& Niina Zhang (eds.), ZAS Papers in Linguistics 22. 1-23.

Bailyn, John Frederick. 2004. The case of Q. In Olga Arnaudova, Wayles Browne, Maria Luisa Rivero \& Danijela Stojanovic (eds.), Proceedings of Annual Workshop on Formal Approaches to Slavic Linguistics 12, 1-35. Ann Arbor, MI: Michigan Slavic Publicatons.

Bailyn, John Frederick \& Andrew Nevins. 2008. Russian genitive plurals are impostors. In Asaf Bachrach \& Andrew Nevins (eds.), Inflectional identity, 237-270. Oxford: Oxford University Press.

Baker, Mark C. 2015. Case: Its Principles and its Parameters. Cambridge: Cambridge University Press. DOI: https://doi.org/10.1017/CBO9781107295186

Bobaljik, Jonathan David. 2008. Where's phi: Agreement as a post-syntactic operation. In Daniel Harbour, David Adger \& Susana Béjar (eds.), Phi theory: Phi-features across interfaces and modules, 295-328. Oxford: Oxford University Press.

Bošković, Željko. 2005. On the locality of left branch extraction and the structure of NP. Studia linguistica 59(1). 1-45. DOI: https://doi.org/10.1111/j.1467-9582.2005.00118.x

Bošković, Željko. 2006. Case checking vs. case assignment and the case of adverbial NPs. Linguistic Inquiry 37. 522-533. DOI: https://doi.org/10.1162/ling.2006.37.3.522

Bošković, Željko. 2008. What will you have, DP or NP? In Emily Elfner \& Martin Walkow (eds.), Proceedings of NELS 37. 101-114. Amherst, MA: Graduate Linguistic Student Association of the University of Massachusetts at Amherst.

Bošković, Željko. 2009. More on the no-DP analysis of article-less languages. Studia linguistica 63(2). 187-203. DOI: https://doi.org/10.1111/j.1467-9582.2009.01158.x

Brattico, Pauli. 2010. One-part and two-part models of nominal case: Evidence from case distribution. Journal of Linguistics 46(1). 47-81. DOI: https://doi.org/10.1017/ S0022226709990193 
Citko, Barbara. 2011. Symmetry in syntax: Merge, move and labels (Vol. 129). Cambridge University Press.

Corbett, Greville G. 1978. Universals in the syntax of cardinal numerals. Lingua 46(4). 355-368. DOI: https://doi.org/10.1016/0024-3841(78)90042-6

Corver, Norbert. 1992. Left branch extraction. In Kimberley Broderick (ed.), Proceedings of NELS 22. 67-84. Amherst, MA: Graduate Linguistic Student Association of the University of Massachusetts at Amherst.

Danon, Gabi. 2012. Two structures for numeral-noun constructions. Lingua 122(12). 1282-1307. DOI: https://doi.org/10.1016/j.lingua.2012.07.003

Doetjes, Jenny Sandra. 1997. Quantifiers and selection: On the distribution of quantifying expressions in French, Dutch and English. Leiden: Leiden University dissertation.

Dziwirek, Katarzyna. 1990. Default agreement in Polish. In Katarzyna Dziwirek, Patrick M. Farrel \& Errapel Majías-Bikandi (eds.), Grammatical Relations, 147-161. Standford, CA: CSLI Publications.

Dziwirek, Katarzyna. 1994. Polish subjects. Taylor \& Francis.

Fanselow, Gisbert \& Damir Čavar. 2002. Distributed deletion. Theoretical approaches to universals, 65-107. DOI: https://doi.org/10.1075/la.49.05fan

Franks, Steven. 1994. Parametric properties of numeral phrases in Slavic. Natural Language \& Linguistic Theory 12(4). 597-674. DOI: https://doi.org/10.1007/BF00992929

Franks, Steven. 1995. Parameters of Slavic morphosyntax. Oxford: Oxford University Press. Franks, Steven. 2002. A Jakobsonian feature based analysis of the Slavic numeric quantifier genitive. Journal of Slavic linguistics, 145-184.

Ionin, Tania \& Ora Matushansky. 2004. A singular plural. In Vineeta Chand, Ann Kelleher, Angelo J. Rodríguez \& Benjamin Schmeiser (eds.), Proceedings of $23^{\text {rd }}$ West Coast Conference on Formal Linguistics, 399-412. Somerville, MA: Cascadilla Press.

Ionin, Tania \& Ora Matushansky. 2006. The composition of complex cardinals. Journal of Semantics 23(4). 315-360. DOI: https://doi.org/10.1093/jos/ffl006

Ionin, Tania \& Ora Matushansky. 2018. Cardinals: The syntax and semantics of cardinalcontaining expressions. Cambridge, MA: MIT Press. DOI: https://doi.org/10.7551/mitpress/8703.001.0001

Jaworska, Ewa. 1986. Prepositional phrases as subjects and objects. Journal of Linguistics 22(2). 355-374. DOI: https://doi.org/10.1017/S0022226700010835

Kayne, Richard. 1981. Binding, quantifiers, clitics and control. In Frank Heny (ed.), Binding and Filtering, 191-211. Cambridge, MA: MIT Press.

Klemensiewicz, Zenon, Tadeusz Lehr-Spławiński \& Stefan Urbańczyk. 1981. Gramatyka historyczna języka polskiego [Historical grammar of Polish]. Warszawa: Polskie Wydawnictwo Naukowe.

Klockmann, Heidi. 2012. Polish numerals and quantifiers: A syntactic analysis of subject-verb agreement mismatches. Utrecht: Utrecht University Master's thesis.

Kornfilt, Jaklin \& Omer Preminger. 2015. Nominative as no case at all: An argument from raising-to accusative in Sakha. In Proceedings of the 9th Workshop on Altaic Formal Linguistics (WAFL 9). Cambridge, MA: MIT Working Papers in Linguistics.

Levin, Maurice I. 1978. Russian Declension and Conjugation. Columbus, OH: Slavica Publishers.

Malchukov, Andrej L. 2006. Transitivity parameters and transitivity alternations. In Leonid Kulikov, Andrej L. Malchukov \& Peter de Swart (eds.), Case, valency and transitivity, 329-357. Amsterdam: John Benjamins Publishing Company. DOI: https:// doi.org/10.1075/slcs.77.21mal

Małecki, Antoni. 1863. Gramatyka języka polskiego większa [Larger grammar of Polish]. Self-published. 
Marantz, Alec. 1991. Case and licensing. In German Westphal, Benjamin Ao \& Hee-Rahk Chae (eds.), Eastern States Conference on Linguistics (ESCOL) 8. Ithaca, NY: DMLL.

McCloskey, James. 1997. Subjecthood and subject positions. In Liliane Haegeman (ed.), Elements of grammar, 197-235. Dordrecht: Springer. DOI: https://doi.org/10.1007/97894-011-5420-8_5

Miechowicz-Mathiasen, Katarzyna. 2011. The syntax of Polish cardinal numerals. Ms. Adam Mickiewicz University.

Miechowicz-Mathiasen, Katarzyna. 2012. Licensing Polish higher numerals: An account of the Accusative Hypothesis. Current Issues in Generative Linguistics 81. 58-75.

Nelson, Diane \& Ida Toivonen. 2000. Counting and the grammar: Case and numerals in Inari Saami. Leeds Working Papers in Linguistics 8. 179-192.

Norris, Mark. 2018. Unmarked case in Estonian nominals. Natural Language \& Linguistic Theory 36(2). 1-40. DOI: https://doi.org/10.1007/s11049-017-9377-9

Ott, Dennis \& Mark de Vries. 2016. Right-dislocation as deletion. Natural Language \& Linguistic Theory 34(2). 641-690. DOI: https://doi.org/10.1007/s11049-015-9307-7

Pereltsvaig, Asya. 2000. On accusative adverbials in Russian and Finnish. Adverbs and adjunction. Linguistics in Potsdam 6. 155-176.

Pereltsvaig, Asya. 2006. Passing by cardinals: In support of head movement in nominals. In James E. Lavine (ed.), Proceedings of Annual Workshop on Formal Approaches to Slavic Linguistics 14. 277-292. Ann Arbor, MI: Michigan Slavic Publications.

Pereltsvaig, Asya. 2008. Split phrases in colloquial Russian. Studia Linguistica 62(1). 5-38. DOI: https://doi.org/10.1111/j.1467-9582.2007.00141.x

Pesetsky, David. 1982. Paths and categories. Cambridge, MA: Massachusetts Institute of Technology dissertation.

Pesetsky, David. 2013. Russian case morphology and the syntactic categories (Vol. 66). Cambridge, MA: MIT Press. DOI: https://doi.org/10.7551/mitpress/978026201 9729.001.0001

Polinsky, Maria. 2016. Deconstructing ergativity: Two types of ergative languages and their features. Oxford: Oxford University Press. DOI: https://doi.org/10.1093/acprof:oso/ 9780190256586.001 .0001

Poole, Ethan. 2016. Deconstructing subjecthood. Ms. University of Massachusetts Amherst.

Preminger, Omer. 2014. Agreement and its failures. Cambridge, MA: MIT Press. DOI: https://doi.org/10.7551/mitpress/9780262027403.001.0001

Przepiórkowski, Adam. 1996. Case assignment in Polish: Towards an HPSG analysis. In Claire Grover \& Enric Vallduví (eds.), Studies in HPSG 12. 191-228. Edinburgh: Centre for Cognitive Science, University of Edinburgh.

Przepiórkowski, Adam. 1999. Case assignment and the complement/adjunct dichotomy: A non-configurational constraint-based approach. Tübingen: University of Tübingen dissertation.

Przepiórkowski, Adam. 2004. O wartości przypadka podmiotów liczebnikowych [On the case value of numeral subjects]. Biuletyn Polskiego Towarzystwa Językoznawczego 60. 133-143.

Przepiórkowski, Adam \& Agnieszka Patejuk. 2012. The puzzle of case agreement between numeral phrases and predicative adjectives in Polish. In Miriam Butt \& Tracy Holloway King (eds.), The Proceedings of the LFG 12 Conference, 490-502. Stanford, CA: CSLI Publications.

Rappaport, Gilbert C. 2003. Case syncretism, features, and the morphosyntax of Polish numeral phrases. Generative Linguistics in Poland 5. 123-137.

Reeve, Matthew. 2010. Clefts. London: University of London dissertation. 
Ruda, Marta. 2011. On coordinate subject-verb agreement in Polish. Handout of ConSOLE XIX Presentation. University of Groningen.

Rutkowski, Paweł. 2002. The syntax of quantifier phrases and the inherent vs. structural case distinction. Linguistic Research 7(1). 43-74.

Rutkowski, Paweł. 2009. Fraza przedimkowa w polszczyźnie [Determiner phrase in Polish]. Warszawa: Wydział Polonistyki Uniwersytetu Warszawskiego.

Sadowska, Iwona. 2012. Polish: A comprehensive grammar. Routledge. DOI: https://doi. org/10.4324/9780203610732

Schütze, Carson T. 2001. On the nature of default case. Syntax 4(3). 205-238. DOI: https:// doi.org/10.1111/1467-9612.00044

Shlonsky, Ur. 2004. The form of Semitic noun phrases. Lingua, 114(12). 1465-1526. DOI: https://doi.org/10.1016/j.lingua.2003.09.019

Silverstein, Michael. 1976. Hierarchy of features and ergativity. In Robert M. W. Dixon (ed.), Grammatical categories in Australian languages, 112-171. Canberra: Australian Institute of Aboriginal Studies.

Sobin, Nicholas. 1997. Agreement, default rules, and grammatical viruses. Linguistic Inquiry 28(2). 318-343.

Szober, Stanisław. 1928. Trzy piękne córki było nas u matki: Formy podmiotu i orzeczenia w zdaniach z podmiotem logicznym, określonym przydawką liczebnikową [There were three of us beautiful daughters at mother's: Subject and predciate forms in sentences with a genitive subject defined by a numeral modifier]. Język Polski, 97-106.

Wągiel, Marcin. 2018. Grammatical Gender Meets Classifier Semantics: Evidence from Slavic Numerals. In Vera Gribanova (ed.), Proceedings of Annual Workshop on Formal Approaches to Slavic Linguistics, 27. Ann Arbour, MI: Michigan Slavic Publications.

Willim, Ewa. 2015. Case distribution and $\varphi$-agreement with Polish genitive of quantification in the feature sharing theory of agree. Poznan Studies in Contemporary Linguistics 51(2). 315-357. DOI: https://doi.org/10.1515/psicl-2015-0013

Woolford, Ellen. 2006. Lexical case, inherent case, and argument structure. Linguistic Inquiry 37(1). 111-130. DOI: https://doi.org/10.1162/002438906775321175

How to cite this article: Lyskawa, Paulina. 2020. The structure of Polish numerically-quantified expressions. Glossa: a journal of general linguistics 5(1): 31.1-37. DOI: https://doi.org/10.5334/gjgl.880
Submitted: 25 December 2018
Accepted: 27 November 2019
Published: 13 March 2020

Copyright: $\odot 2020$ The Author(s). This is an open-access article distributed under the terms of the Creative Commons Attribution 4.0 International License (CC-BY 4.0), which permits unrestricted use, distribution, and reproduction in any medium, provided the original author and source are credited. See http://creativecommons.org/licenses/by/4.0/. 